\title{
The Three Seas Initiative: geographical determinants, geopolitical foundations, and prospective challenges
}

\author{
Inicijativa triju mora: geografske odrednice, \\ geopolitička utemeljenja i budući izazovi
}

The Three Seas (Baltic-Adriatic-Black) Initiative was originally rationalised as a geopolitical alliance of NATO/EU member states of "New Europe", from Estonia to Croatia, connecting the Baltic and Adriatic Seas. The member states, with the exception of Austria, share certain common denominators, such as communist history and NATO membership, prior to EU membership. The idea resembles the geopolitical idea of Intermarium, which was envisioned as a federation of independent Central and Eastern European states, based mostly on the ethnic principle. At present day, the Initiative is also intended to contain the influence of Russia and pull the states between EU/NATO and Russia out of the Russian sphere of influence. The post-communist NATO/EU member states are bandwagoning towards the U.S. and perceive NATO as the guarantor of their security. The Three Seas Initiative represents a geopolitical wedge between EU/Bruxelles and Moscow or, in geopolitical and historical terms, between Germany and Russia.

Key words: The Three Seas Initiative, Intermarium, Central and South-Eastern Europe, the Visegrad Group, NATO, Russia, Geopolitics.
Inicijativa triju mora (Baltičko, Jadransko i Crno more) izvorno je zamišljena kao geopolitički savez država članica NATO-a i EU-a iz "Nove Europe”, kao poveznica Baltičkoga i Jadranskoga mora, od Estonije do Hrvatske. Države članice, osim Austrije, imaju zajedničke nazivnike: komunističku prošlost i članstvo u NATO-u koje je prethodilo članstvu u EUu. Ideja podsjeća na geopolitičku ideju Intermariuma, zamišljenog kao federacija neovisnih država srednje i istočne Europe, uglavnom zasnovana na načelu etniciteta. Današnji je smisao Inicijative zadržavanje utjecaja Rusije i izvlačenje država smještenih između NATO-a odnosno EU-a i Rusije iz sfere ruskoga utjecaja. Postkomunističke članice NATO-a i EU-a priklanjaju se SAD-u i doživljavaju NATO kao jamca vlastite sigurnosti. Inicijativa triju mora geopolitički je klin između Bruxellesa i Moskve, odnosno, u geopolitičkom i povijesnom smislu, između Njemačke i Rusije.

Ključne riječi: Inicijativa triju mora, Intermarium, srednja i jugoistočna Europa, Višegradska skupina, NATO, Rusija, geopolitika. 
HRVATSKI

GEOGRAFSKI

GLASNIK

80/1,99-124 (2018.)

\section{Introduction}

The Three Seas (Baltic-Adriatic-Black, BABS) Initiative, was originally initiated in 2015 as the Adriatic-Baltic Sea Initiative by the Croatian President Kolinda Grabar-Kitarović, and has also been referred to as the $\mathrm{ABC}$ (Adriatic, Baltic, and Black $\mathrm{Sea}^{1}$ ) Initiative (first designated as such by Polish President Andrzej Duda) in Poland and Croatia (its main protagonist countries), or "the Vertical", considering the generally predominant direction of the bloc of countries, which comprise this Initiative (north to south). With the inclusion of Bulgaria and Romania, the Adriatic-Baltic Sea Initiative became the Three Seas Initiative (hereafter, the Initiative). The Initiative is an alliance of post-communist NATO and European Union (hereafter: the EU) member states of Rumsfeld's "New Europe", from Estonia in the north to Croatia in the southwest, and Bulgaria in the southeast, plus Austria. The president of Croatia sees Bosnia and Herzegovina as the possible future member of the Initiative. All member states, except Austria, share several common denominators, such as recent communist past and NATO membership, obtained prior to EU accession.

The idea of the Initiative seems like a revival, adjusted to the contemporary era, of the geopolitical idea of Intermarium, which was envisioned as a federation of independent Central and East European states, based mainly on the ethnic principle. After the First World War, that would mean an imminent dissolution of the Soviet Russia/Soviet Union. The contemporary Initiative has similar goals - containing the influence of Russia and drawing the area between NATO/ EU and Russia (Ukraine, Belarus, and Moldova) out of the Russian sphere of influence, as well as keeping foothold in the Caucasus (Georgia), and thereby promoting the interests of the U.S., as the great power--emulating the Inter-War period influence of France--in the region. The member states of the Initiative are bandwagoning towards the U.S. and perceive $\mathrm{NATO}$ as the guarantor of their security. They mostly share what are, in liberal European political thought, designated as illiberal (conservative) tendencies. The Visegrad Group states (Czech Republic, Hungary,

1 The Polish term for the Black Sea is Morze (sea) Czarne (black), while the Croatian term is Crno more.

\section{Uvod}

Inicijativu triju mora (Baltičko, Jadransko i Crno more) pokrenula je, izvorno kao Inicijativu Jadran-Baltik, predsjednica Republike Hrvatske K. Grabar-Kitarović 2015. godine. U Poljskoj i Hrvatskoj (glavnim državama promicateljima) još se naziva i $\mathrm{ABC}$ inicijativom, ${ }^{1}$ kako ju je prvi put nazvao poljski predsjednik Duda, odnosno Uspravnicom, s obzirom na prevladavajući smjer pružanja bloka država koje ju čine (sjever-jug). Uključivanjem Bugarske i Rumunjske Inicijativa Jadran-Baltik postala je Inicijativa triju mora (dalje u tekstu: Inicijativa). Inicijativa je u biti savez postkomunističkih država članica NATO-a i Europske unije (dalje u tekstu: EU), iz Rumsfeldove „Nove Europe”, od Estonije na sjeveru do Hrvatske na jugozapadu i Bugarske na jugoistoku, a uključuje i Austriju. Predsjednica Republike Hrvatske kao buduću članicu Inicijative vidi i Bosnu i Hercegovinu. Sve države članice, izuzev Austrije, imaju nekoliko zajedničkih obilježja, kao što su (još) nedavna komunistička prošlost i članstvo u NATO-u, koje je bilo ulaznica za članstvo u EU-u.

Ideja Inicijative čini se kao oživljavanje, prilagođeno suvremenom razdoblju, geopolitičke ideje Intermariuma, koji je bio zamišljen kao federacija neovisnih država srednje $\mathrm{i}$ istočne Europe, uglavnom zasnovana na načelu etniciteta. Nakon Prvoga svjetskog rata to bi značilo trenutačan raspad Sovjetske Rusije, tj. Sovjetskoga Saveza. Suvremena Inicijativa ima slične ciljeve - zaustavljanje utjecaja Rusije i izvlačenje prostora između NATO-a/ EU-a i Rusije (Ukrajina, Bjelorusija, Moldavija) iz sfere ruskoga utjecaja, sa zadržavanjem uporišta na Kavkazu (Gruzija), te shodno tomu pogodovanje interesima Sjedinjenih Američkih Država (dalje u tekstu: SAD), kao velesile koja je u regiji naslijedila utjecaj Francuske iz razdoblja između dvaju svjetskih ratova. Države članice Inicijative priklanjaju se SAD-u i doživljavaju NATO kao jamca vlastite sigurnosti. Umnogome pak dijele ono što se u europskoj političkoj misli naziva neliberalnim (konzervativnim) tendencijama. Države članice

\footnotetext{
1 Prema poljskim nazivima za Jadransko, Baltičko i Crno more.
} 


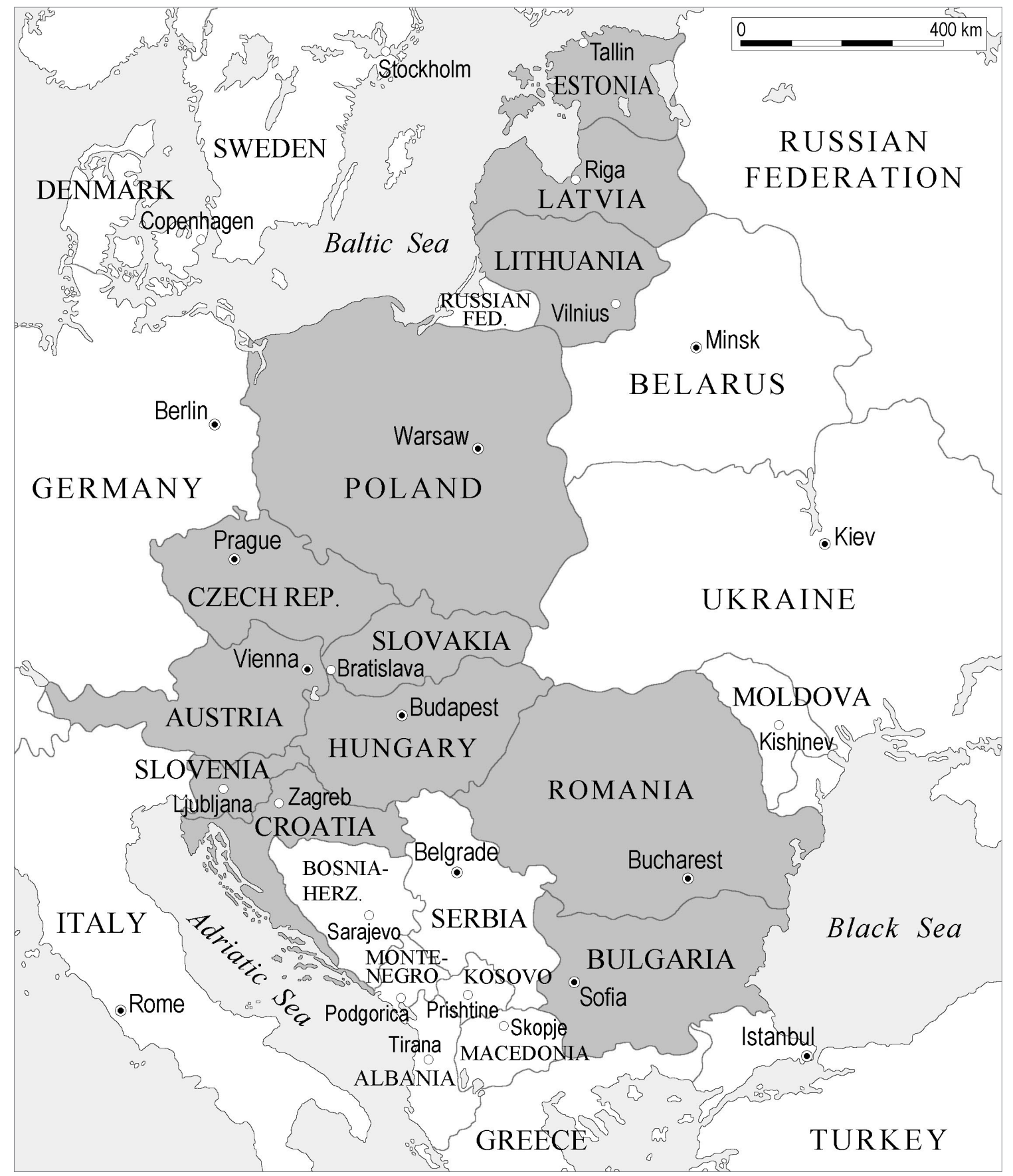

Fig. 1 The Three Seas Initiative member states

SI. 1. Države članice Inicijative Tri mora

Poland, and Slovakia) are sometimes referred to as "illiberal democracies" (Illiberal Democracies in the EU, 2017), which share an objection towards the acceptance of refugees according to EU-imposed quotas, and "reluctance" or clear opposition to "Bruxelles", i.e.
The Three Seas Initiative: geographical determinants, geopolitical foundations, and prospective challenges

Inicijativa triju mora: geografske odrednice, geopolitička utemeljenja i budući izazovi tzv. Višegradske skupine (Češka Republika, Mađarska, Poljska, Slovačka) katkad se nazivaju „neliberalnim demokracijama” (Illiberal Democracies in the EU, 2017), koje dijele protivljenje primanju izbjeglica sukladno kvotama usvojenima na razini 
HRVATSKI

GEOGRAFSKI

GLASNIK

80/1,99-124 (2018.) the power of the EU as a whole. The Visegrad Group is the main proponent of the idea of the $\mathrm{EU}$ as a community of national states, in opposition to the idea of establishing further political integration of $\mathrm{EU}$ states, and are especially opposed to the idea of the $\mathrm{EU}$ as a federation. These opposing tendencies are widening the rising East-West gap within the EU. Additionally, the Initiative represents a geopolitical wedge between "Bruxelles" and Moscow or, in geopolitical and historical terms, between Germany and Russia. It is the main intention of this paper to study the geographical determinants, geopolitical foundations, and the contemporary motives and goals of the Initiative, as well as the Initiative's role in the geopolitical relations of the U.S./EU core states/Russia triangle (Fig. 1).

\section{The Three Seas Initiative in the context of the Pivot and Heartland theories}

In the first half of the $20^{\text {th }}$ century, Sir Halford J. Mackinder used the term Eastern Europe ${ }^{2}$ to describe the whole eastern part of the European continent. The term was also used for the same purpose during the Cold War era. Before the First World War, the term described the eastern parts of the German and Austro-Hungarian empires, as well as the westernmost parts of the Russian Empire. After the First World War, eastern parts of the region (then Eastern Europe) mostly became the part of Soviet Russia (which became The Soviet Union in 1922), while the westernmost parts of this region, plus Eastern Prussia, remained a part of Germany. However, both states were reduced in their territorial reach. In the central part of the region(s) a belt of small and mid-size states, surrounding Germany to the northeast, east and southeast, emerged as a geopolitical

2 For the purpose of this paper, to designate the contemporary realities and to limit the scope to the Initiative's member states, the term Central Europe signifies the following post-communist NATO/EU members: the Baltic States (Estonia, Latvia, and Lithuania), Poland, the Czech Republic, Slovakia, Hungary, and Slovenia. The term South-Eastern Europe signifies Bulgaria, Romania, and Croatia, which joined the EU in 2007 and 2013, respectively. The term Eastern Europe, is not used to designate this space in the contemporary context; hence the region is no longer overlaid by Soviet influence, and the borders of the geopolitical East have moved to the east (if the Soviet Union and not the Warsaw Treaty borders are taken into account, Kaliningradska oblast and Belarus are the exceptions). Therefore, in the contemporary context, in this paper, the term Eastern Europe does not signify any of the present EU/NATO member states. It signifies Belarus, Ukraine, Moldova, and the European part of Russia.
EU-a te „nevoljkost” ili protivljenje Bruxellesu, tj. moći EU-a kao cjeline. Višegradska skupina glavni je promicatelj ideje EU-a kao zajednice nacionalnih država, suprotnosti ideji uspostave EU-a kao političke integracije, a posebice se protive ideji EU-a kao federacije. Te suprotstavljene tendencije nastavljaju širiti postojeći jaz između istoka i zapada u EU-u. K tomu, Inicijativa predstavlja geopolitički klin između Bruxellesa i Moskve, odnosno, geopolitički i povijesno gledano, između Njemačke i Rusije. Primarna je namjera ovoga rada istražiti geografske odrednice, geopolitička utemeljenja te suvremene motive i ciljeve Inicijative te njezinu ulogu u trokutu odnosa SAD - države jezgre EU-a - Rusija (sl. 1).

\section{Inicijativa triju mora u kontekstu teorija $\mathrm{H}$. J.} Mackindera

U prvoj polovini 20. stoljeća Sir Halford J. Mackinder čitavu je istočnu polovicu europskoga kontinenta smatrao istočnom Europom..$^{2}$ Naziv se u istu svrhu upotrebljavao i tijekom hladnoratovskoga razdoblja. Prije Prvoga svjetskog rata pojam je označavao istočne dijelove Njemačkoga i Austro-Ugarskoga Carstva te najzapadnije dijelove Ruskoga Carstva. Nakon Prvoga svjetskog rata istočni dijelovi regije (tadašnja istočna Europa) uglavnom su postali dijelom sovjetske Rusije (od 1922. godine Sovjetskoga Saveza), a najzapadniji dijelovi, uz Istočnu Prusku, ostali su u Njemačkoj. Međutim, obje države doživjele su smanjenje teritorijalnoga opsega. U središnjem dijelu regije kao geopolitička stvarnost pojavljuje se pojas malih država i država srednje veličine koji sa sjeveroistoka, istoka i jugoistoka

$2 \mathrm{Za}$ potrebe ovoga rada, kako bi se označila suvremena realnost i oznake ograničilo na države Inicijative, naziv srednja Europa označuje sljedeće postkomunističke države članice NATO-a i EU-a: baltičke države (Estonija, Latvija, Litva), Poljsku, Češku Republiku, Slovačku Republiku, Mađarsku i Sloveniju. Naziv jugoistočna Europa označuje Bugarsku, Rumunjsku i Hrvatsku, koje su se EU-u priključile 2007. i 2013. godine. Naziv istočna Europa se u suvremenom kontekstu ne upotrebljava za ovaj prostor jer regija više nije pod sovjetskim utjecajem, a granice geopolitičkoga istoka pomakle su se na istok (ako se računaju granice Sovjetskoga Saveza, a ne Varšavskoga ugovora, Kalinjingradska oblast i Bjelorusija su jedini izuzetci, inače ih ne bi ni bilo). Stoga naziv istočna Europa u ovom radu u suvremenom kontekstu ne označuje niti jednu državu članicu EU-a i NATO-a, nego se upotrebljava za označavanje Bjelorusije, Ukrajine, Moldavije i europskoga dijela Rusije. 
reality, separating Germany from the Soviet Union. It was named Middle Tier by Mackinder, and it described the countries between the Baltic, Adriatic, and the Black Seas - geographical location determinants and precisely what the Initiative has as its founding principle, to align the states between the three aforementioned seas. This belt of states later became known as cordon sanitaire (the term emphasised its purpose - the separation of Germany's territory from the territory of the Soviet Union), and it was also pejoratively christened the Teufels Gürtel ${ }^{3}$ (Devil's Belt) by Haushofer and the German Geopolitik, which sought the possibility of retribution for the defeat in the First World War. After the Second World War, what emerged on a similar portion of geographical space, besides an even more territorially-reduced (and divided) Germany, were mostly the same small and mid-sized states, under the overwhelming influence of Soviet military might, located in the centre of Europe. After the breakup of the Soviet Union and the reunification of Germany, the region again became prone to geopolitical pressures - U.S./NATO pressure from the enlarged geopolitical West and the rebuttal of that pressure from the now shrunken geopolitical East, reduced to Russia and its ally Belarus.

It is exactly to this space that Mackinder referred when he described the importance of Eastern Europe in the world's history (and especially its importance at the beginning of the $20^{\text {th }}$ century, when he started devising his ideas, drawing on his knowledge about the geography of Eurasia). In Mackinder's paper, titled The Geographical Pivot of History (1904), Eastern Europe represented the geographically most convenient entrance to the Pivot (i.e. the Geographical pivot of history). Domination over the Pivot was a key for domination over Eurasia, and domination over Eurasia was the key to world domination. In Mackinder's book Democratic Ideals and Reality, published in 1919, after the outcome of the First World War was known, the spread of Pivot was enlarged (it comprised the whole eastern half of Europe) and it was renamed to the Heartland.

3 The emergence of mostly small states in the eastern parts of Central Europe, i.e. Eastern Europe, as the region was known in various parts of the $20^{\text {th }}$ century, was pejoratively named Kleinstaatengerümpel, a rubbish of small states that were supposed to be substituted by various forms of governance under German (Nazi-led) New European Order. See: Parker, G. 2014: Western Geopolitical Thought in the $20^{\text {th }}$ Century, Routledge, London, 186. okružuje Njemačku te je odvaja od Sovjetskoga Saveza. Mackinder je ovaj pojas nazvao Middle Tier 'Srednji stup', a odnosio se na države između Baltičkoga, Jadranskoga i Crnoga mora, čije su odrednice utemeljenje za osnivanje Inicijative stvaranje saveza država između triju spomenutih mora. Ovaj pojas država kasnije postaje poznat pod nazivom cordon sanitaire 'sanitarni pojas' (naziv označava njegovu svrhu, odvajanje teritorija Njemačke od teritorija Sovjetskoga Saveza). Navedeni su pojas Haushofer i njemački Geopolitik, tražeći mogućnost odmazde za poraz u Prvom svjetskom ratu, nazvali Teufels Gürtel 3 "Vražji pojas". Nakon Drugoga svjetskog rata na sličnom dijelu geografskoga prostora osim još više teritorijalno umanjene (i podijeljene) Njemačke nastale su opet uglavnom male države i države srednje veličine pod prevladavajućim utjecajem sovjetske vojne moći u središtu Europe. Nakon raspada Sovjetskoga Saveza i ujedinjenja Njemačke regija je ponovno postala izložena geopolitičkim pritiscima - pritisku SAD-a i NATO-a s proširenoga geopolitičkog zapada i odupiranju tomu pritisku umanjenoga geopolitičkog istoka, svedenog na Rusiju i njezinu saveznicu Bjelorusiju.

To je prostor na koji se referirao Mackinder, imajući na umu geografiju Euroazije, kada je opisivao važnost istočne Europe u povijesti svijeta (a pogotovo njezinu važnost na početku 20. stoljeća, kada je počinjao razvijati svoje ideje). U Mackinderovu članku Geographical Pivot of History (1904) istočna Europa geografski je najpogodniji ulaz u Stožer (Pivot, Geografski stožer povijesti). Dominacija nad Stožerom bila je ključ za prevlast nad Euroazijom, a prevlast nad Euroazijom bila je ključ svjetske prevlasti. U Mackinderovoj knjizi Democratic Ideals and Reality, objavljenoj 1919. g. nakon što je bio poznat ishod Prvoga svjetskog rata, opseg Stožera je veći (obuhvaćao je cijelu istočnu polovicu Europe) te mu je ime promijenjeno u Heartland "Srce zemlje”.

3 Pojava većinom malih država u istočnom dijelu stednje Europe, tj. istočne Europe, pod kojim je nazivom regija bila poznata u pojedinim razdobljima 20. stoljeća, pogrdno je nazvano Kleinstaatengerümpel 'Otpad malih država', koje su trebale biti zamijenjene različitim oblicima vladavine pod njemačkim (nacističkim) Novim europskim poretkom. Parker, G. 2014: Western Geopolitical Thought in the $20^{\text {th }}$ Century, Routledge, London, 186.
The Three Seas Initiative: geographical determinants, geopolitical foundations, and prospective challenges

Inicijativa triju mora: geografske odrednice, geopolitička utemeljenja i budući izazovi 
HRVATSKI

GEOGRAFSKI

GLASNIK

80/1, 99-124 (2018.)
On the centennial of Mackinder's afore-mentioned famous paper, published in the Geograpbical Journal, Paul Kennedy, Yale historian, wrote an article titled The Pivot of History, about Mackinder's ideas and their contemporary significance. Writing in a period when the U.S.-UK led occupation of Iraq was beginning to look more like a mild success, Kennedy was also pointing to Mackinder's contemporary geopolitical resonances: 'Right now, with hundreds of thousands of U.S. troops in the Eurasian rimlands and with an administration constantly explaining why it has to stay on the course, it looks as if Washington is taking seriously Mackinder's injunction to ensure control of "the geographical pivot of history". Some of today's U.S. neo-conservative intellectuals make admiring reference to former British rule in that region, and have called for the creation of a U.S. 'colonial office' (Kennedy, 2004, in Dodds and Sidaway, 2004: 292)”.

It also has to be emphasised that, in his rationalizations, Mackinder gave preference to geographical over human quantities, because 'the geographical quantities are more measurable and more nearly constant' (Mackinder, 1904: 437). Accentuating the importance of geography in his later published speech, Mackinder explained his view on the factors that determine the balance of power, and also emphasised the central position of Germany in Europe. According to Mackinder, Germany was to Europe what Russia was to the world - a central power. What was particularly worrisome for Mackinder was the possibility that Russia would become too powerful. He also predicted that it would be particularly dangerous if Germany was to ally itself with Russia (Mackinder, 1904: 436).

The Initiative fits into Mackinder's world view and represents a contemporary reply to one of his most important geopolitical ideas:

- First, the northern part of the Initiative is located in the part of Mackinder's Inner Crescent, from which the Russian core can be successfully attacked, due to its relative closeness, and the lowlands that prevail in the geography of this space, without real natural barriers. Although it seems like a distant possibility at present day, the invasions of the Russian core were attempted successfully up to a critical point for Russia in 1812 and the Soviet Union in 1941. In contemporary con-
$\mathrm{Na}$ stotu obljetnicu objave spomenutoga slavnog Mackinderova članka, objavljenog u Geographical Journal, povjesničar sa Sveučilišta Yale Paul Kennedy napisao je članak The pivot of history o Mackinderovim idejama i njihovu suvremenom značaju. Pišući u razdoblju dok je okupacija Iraka, koju su vodile SAD i Ujedinjeno Kraljevstvo, izgledala uspješno, Kennedy je isticao Mackinderove suvremene geopolitičke odjeke: „Upravo sada sa stotinama tisuća američkih postrojbi u rubnim dijelovima Euroazije i vladom koja neprekidno objašnjava zašto mora zadržati ovaj smjer (politiku) čini se kao da Washington ozbiljno shvaća Mackinderov nalog o osiguravanju kontrole nad 'geografskim stožerom povijesti'. Neki od suvremenih američkih neokonzervativnih intelektualaca daju izjave pune poštovanja za nekadašnju britansku vladavinu u regiji te su pozvali na stvaranje 'kolonijalnog ureda' SAD-a" (Kennedy, 2004, u: Dodds i Sidaway, 2004: 292).

Treba naglasiti da je Mackinder u svojim promišljanjima davao prednost geografskim kvantitetama nad antropogenim zato što su "geografske kvantitete mjerljivije i gotovo potpuno konstantne“ (Mackinder, 1904: 437). Naglašujući važnost geografije u kasnije objavljenom govoru, Mackinder je objasnio svoje viđenje čimbenika koji određuju ravnotežu snaga te je istaknuo središnju poziciju Njemačke u Europi. Po njemu je Njemačka bila za Europu ono što je Rusija bila za svijet - središnja sila. Mackindera je pak posebno zabrinjavala mogućnost da Rusija postane prejaka. Također je predvidio da bi bilo posebno opasno kad bi se Njemačka povezala s Rusijom (Mackinder, 1904: 436).

Inicijativa se dakle uklapa u Mackinderovo videnje svijeta i predstavlja suvremeni odgovor na jednu od njegovih najvažnijih geopolitičkih ideja jer:

- Prvo, sjeverni dio Inicijative nalazi se u dijelu Mackinderova Inner Crescent 'Unutarnjega prstena', iz kojega se može uspješno napasti jezgra Rusije, s obzirom na njezinu blizinu i nizine koje prevladavaju u reljefu ovoga prostora, bez pravih prirodnih prepreka. Iako se ovo u sadašnjosti čini malo vjerojatnim, invazije na jezgru Rusije uspješno su izvedene sve do kritične točke za Rusiju 1812. godine i za Sovjetski Savez 1941. godine. U suvremenim 
ditions, only Belarus serves as cordon sanitaire for Russia, while NATO has a higher depth of possible battlefield.

- Second, the opposite aspect of the Initiative's geographical position is comprised in the fact that Russia's influence and a possible threat must be contained in the Baltic region, as the border of NATO has moved significantly to the east. Therefore, the Initiative, supported by Initiative's and NATO's member states troops, serves as a deterrent.

- Third, by its geographical position, the Initiative is fitted and destined to geographically separate and therefore contain the influence of two land-based powers, Russia and Germany, which are today still central by their geographical location (Germany for Europe, and Russia for Eurasia). Concurrently, their geopolitical positions are quite different. Mackinder's prognosis that a world empire might be visible if Germany was to ally herself with Russia at present seems unrealistic. However, Germany and Russia need not to formally ally themselves in order to achieve the dominance in the western and central part of Eurasia - because this dominance is encoded in their geography and capabilities. Apart from their geographical positions, the dominance of Germany and Russia in the greater part of continental Eurasia is based on the productive and (in general) economic capabilities of Germany and the abundance of raw materials, especially oil and natural gas, as well as the military capabilities of Russia. Their economic cooperation, despite formally tightened political relations, terrifies U.S. policy makers up to a point that they are passing the laws that are indirectly trying to prevent any new cooperation, particularly in the domain of energy (e.g. Nord Stream 2 gas pipeline).

\section{Other geographers that have addressed the geopolitical significance of Central and Eastern Europe}

J. F. Unstead (1923) called East-Central Europe the "belt of political change in Europe", because of the great instability that haunted the area. Geographical barriers, repeated intrusions by neighbouring major powers, as well as mutual fears and uvjetima samo Bjelorusija služi kao cordon sanitaire Rusiji, dok NATO ima veću dubinu mogućega ratišta.

- Drugo, suprotno viđenje geografskoga položaja Inicijative sastoji se u činjenici da se utjecaj Rusije mora zaustaviti na Baltiku jer se granica NATO-a prilično pomaknula na istok. Stoga Inicijativa, koju podupiru postrojbe država članica Inicijative i NATO-a, služi kao sredstvo odvraćanja.

- Treće, prema svojem geografskom položaju Inicijativa je pogodna i predodređena da geografski razdvaja i tako zaustavlja utjecaj dviju kopnenih sila Rusije i Njemačke, koje su i danas središnje po svojem smještaju (Njemačka u Europi, Rusija u Euroaziji). Istovremeno su njihovi geopolitički položaji prilično drugačiji. Mackinderovo predviđanje da bi svjetsko carstvo moglo biti na vidiku ako bi se Njemačka povezala s Rusijom danas se čini nerealnim. Međutim, Njemačka i Rusija ne moraju formalno postati saveznice kako bi ostvarile dominaciju u zapadnom i središnjem dijelu Euroazije jer je ova dominacija utemeljena u njihovoj geografiji i kapacitetima. Osim geografskoga položaja dominacija Njemačke i Rusije u većem dijelu kontinentske Euroazije zasniva se na proizvodnim i općenito gospodarskim kapacitetima Njemačke te bogatstvu prirodnih izvora, posebice nafte i plina, te vojnim kapacitetima Rusije. Njihova gospodarska suradnja, usprkos formalno zategnutim političkim odnosima, plaši planere američke politike do te mjere da se u Kongresu SAD-a donose zakoni koji pokušavaju na neizravan način zaustaviti bilo kakvu buduću suradnju, pogotovo u području energetike (plinovod Sjeverni tok 2).

\section{Ostali geografi koji su istraživali geopolitičko značenje srednje i istočne Europe}

J. F. Unstead (1923) srednju i istočnu Europu nazvao je „pojasom političke promjene u Europi” zbog velike nestabilnosti koja je prijetila regiji. Geografske prepreke, opetovani upadi susjednih velikih sila kao i međusobni strahovi i zavisti među
The Three Seas Initiative: geographical determinants, geopolitical foundations, and prospective challenges

Inicijativa triju mora: geografske odrednice, geopolitička utemeljenja i budući izazovi 
HRVATSKI

GEOGRAFSKI

GLASNIK

80/1, 99-124 (2018.) envies between the states of the belt had caused great economic and political difficulties.

James Fairgrieve, an intellectual disciple of Mackinder, in earlier editions of his book Geography and World Power, identified the dominant geographical feature of the Old World as the central 'heartland' of 'Euro-Asia', which, 'occupies, from the very fact of its effective centrality and size, a unique position in the world'. What is important for this paper, emphasizing the importance of Germany, is that Fairgrieve identified Germany as one of the three centres from which the Eurasian heartland could be politically controlled by outside ocean powers (the other two were China and India): 'In touch with the sea and tempted on to the ocean, Germany is one of the sea powers, while her situation on the western and most populous margin of the great heartland makes her (...) a possible centre from which the heartland might be organized'. $\mathrm{He}$ also coined the term crush zone (Fairgrieve, 1924), to describe the areas around the edges of the Heartland (later known as the shatterbelt of Eastern Europe), mostly comprised of small buffer states. The most important crush zones were Eastern Europe, the Near East, and the maritime parts of China (Hensel and Diehl, 1994: 38).

Richard Hartshorne (1941) and Derwent Whittlesey (1942) blamed the relative weakness of East-Central European states for Germany's expansion in the Second World War (Hensel and Diehl, 1994: 38). Hartshorne (1944) wrote about a shatter zone in Europe that would emerge after the Second World War. At that time, it was still not known that it would fall under Stalin's exclusive influence. Hartshorne also advocated for the establishment of a federation of states, as a solution for this unstable region that was under constant pressure from its more powerful neighbours. Whittlesey, who, like Carl Sauer at Berkeley, mentored a doctoral programme at Harvard in the 1950s (which was small but very distinguished and influential - much beyond what its size might suggest (Armstrong and Martin, 2006)) coined the term shatterbelt, which became one of the most known terms and concepts in political geography and geopolitics in the second half of the $20^{\text {th }}$ century.

Saul B. Cohen, one of Whittlesey's most distinguished disciples, duly credited for the continuous državama u pojasu uzrokovali su velike gospodarske i političke teškoće.

James Fairgrieve, Mackinderov učenik, u ranijim izdanjima svoje knjige Geography and World Power identificirao je dominantnu geografsku značajku Staroga svijeta kao središnjega „srca zemlje“ (heartland) Euroazije“, koje „zauzima, zbog svojega središnjeg položaja i veličine, jedinstven položaj u svijetu“. Ono što je važno za ovaj članak, a tiče se naglašavanja važnosti Njemačke, jest da je Fairgrieve prepoznao Njemačku kao jedno od triju središta moći (ostala dva bila su Kina i Indija) iz kojega vanjske oceanske sile mogu politički kontrolirati „srce zemlje“ Euroazije: „U dodiru s morem i izazvana oceanom Njemačka je jedna od pomorskih sila, dok ju njezin položaj na zapadnom i naseljenom rubu velikoga „srca zemlje“ čini (...) mogućim središtem iz kojega se „srce zemlje“ može organizirati." Također je skovao naziv crush zone 'pojas pritiska' (Fairgrieve, 1924) kako bi opisao prostore oko rubova Heartlanda (poslije poznate kao shatterbelt 'pojas drobljenja' istočne Europe), na kojima su uglavnom opstojale male tzv. tampon-države. Najvažnija takva područja bila su istočna Europa, Bliski istok i primorski dijelovi Kine (Hensel i Diehl, 1994: 38).

Richard Hartshorne (1941) i Derwent Whittlesey (1942) krivili su relativnu slabost država istočne i srednje Europe za ekspanziju Njemačke u Drugom svjetskom ratu (Hensel i Diehl, 1994: 38). Hartshorne (1944) je pisao o shatter zone u Europi, koja će nastati nakon Drugoga svjetskog rata. Tada se još uvijek nije znalo da će pasti pod isključivi Staljinov utjecaj. Hartshorne je također zagovarao uspostavu federacije država kao rješenje za ovu nestabilnu regiju koja je konstantno bila pod pritiskom svojih moćnijih susjeda. Whittlesey, tijekom 1950-ih godina mentor maloga, ali vrlo poznata i utjecajnog (mnogo više nego što bi to sugerirala njegova veličina) doktorskoga studija na Berkeleyu (kao i Carl Sauer) (Armstrong i Martin, 2006), skovao je naziv shatterbelt, koji je postao jedan od najpoznatijih koncepata u političkoj geografiji i geopolitici u drugoj polovini 20. stoljeća.

Saul B. Cohen, jedan od najpoznatijih Whittleseyjevih učenika, kojem se ispravno pripisuje kon- 
use of this term (and the development of the concept as well), incorporated the model of shatterbelt into his regional model of the world, while the works of the previously mentioned geographers usually concentrated on Eastern Europe - which in the Cold War was not a shatterbelt. In the 1990s, due to large geopolitical changes, Cohen started to perceive the region that again became known as Central and Eastern Europe in the literature, as a gateway region, a region of possible openness and trade that would increase its economic growth and stability. However, in the book titled Geopolitics of the World System (Cohen, 2003: 44), Cohen leaves the possibility of the new/old zone, from the Baltic to Eastern Europe to the Balkans, becoming a shatterbelt again. In the more recent book, titled Geopolitics - The Geography of International Relations (Cohen, 2008), the space from Norway and Finland to the Baltic and Central, Eastern and South-Eastern Europe, is represented as the western part of the Eurasian Convergence Zone, that surrounds Russia (and China), and is prone to geopolitical pressures from two directions outward from Russia and inward from the U.S.. NATO's eastern enlargement has increased the inward pressure in the European part of the Zone.

The thought about the near constant value and influence of geography, although with a lesser degree of importance given to geography in Nicholas J. Spykman's earlier works, was later present in his landmark book The Geography of the Peace (1944), published after his death. Although Spykman was not a geographical determinist, he recognised the importance of geography for a country's history, present, and future: 'The factors that condition the policy of states are many; they are permanent and temporary, obvious and hidden; they include, apart from the geographic factor, population density, the economic structure of the country, the ethnic composition of the people, the form of government, and the complexes and pet prejudices of foreign ministers' (Spykman, 1938: 28) ${ }^{4}$. And while he recognised the importance of Heartland, Spykman accentuated the importance of control over Rimland, a

\footnotetext{
4 Geography was important, but not the only important thing determining a country's destiny: "the geography of a country is rather the material for, than the cause of, its policy, and to admit that the garment must ultimately be cut to fit the cloth is not to say that the cloth determines either the garment's style or its adequacy. But the geography of a state cannot be ignored by men who formulate its policy" (Spykman, 1938: 30).
}

tinuirana upotreba ovoga naziva (i također razvoj koncepta), uklopio je model shatterbelta u svoj regionalni model svijeta. Radovi ranije spomenutih geografa uglavnom su bili koncentrirani na istočnu Europu, no ona tijekom Hladnoga rata nije bila shatterbelt. U 1990-ima, zbog velikih geopolitičkih promjena, Cohen je regiju koja se u literaturi opet počela nazivati srednjom i istočnom Europom, smatrao gateway-regijom (regijom povezivanja), regijom moguće otvorenosti i trgovine, koje bi povećale njezin ekonomski rast i stabilnost. Međutim, u knjizi Geopolitics of the World System (Cohen, 2003: 44) Cohen ostavlja otvorenom mogućnost da nova/ stara zona, od Baltika preko istočne Europe do Balkana, opet postane shatterbelt. U novijoj knjizi Geopolitics - The Geography of International Relations (Cohen, 2008) prostor od Norveške i Finske, preko Baltika, uključujući srednju, istočnu i jugoistočnu Europu, prikazan je kao zapadni dio Euroazijske zone konvergencije, koja okružuje Rusiju (i Kinu) te je podložna geopolitičkim pritiscima iz dvaju smjerova - prema van, iz Rusije, te prema unutrašnjosti, primarno iz SAD-a. Proširenje NATO-a na istok povećalo je pritisak prema unutrašnjosti u europskom dijelu pojasa.

Misao o gotovo stalnoj vrijednosti i utjecaju geografije, iako s manjim stupnjem važnosti koji joj se pripisuje, kasnije je prisutna u ranijim djelima Nicholasa J. Spykmana, kao i u remek-djelu The Geography of the Peace (1944), objavljenom nakon njegove smrti. Iako Spykman nije bio geografski determinist, priznavao je važnost geografije za povijest, sadašnjost i budućnost države: „Čimbenici koji uvjetuju politiku država su brojni; stalni su i privremeni, očiti i skriveni; te uključuju, osim geografskoga čimbenika, gustoću stanovništva, gospodarsku strukturu države, etnički sastav stanovništva, oblik vladavine te komplekse i predrasude ministara vanjskih poslova" (Spykman, 1938: 28). ${ }^{4}$ Iako je priznavao važnost Heartlanda, Spykman je naglašavao važnost kontrole nad Rimlandom 'Rubnom zemljom', pojmom izravno izvedenim iz poj-

4 Geografija je bila važna, ali ne jedina važna stvar koja određuje sudbinu države: „Geografija države je više materijal nego uzrok njezine politike. Priznavati da tkanina mora biti odrezana kako bi odgovarala odjeći ne znači smatrati da odjeća određuje stil ili prikladnost tkanine. Međutim, geografiju države ne mogu ignorirati ljudi koji oblikuju njezinu politiku" (Spykman, 1938: 30).
The Three Seas Initiative: geographical determinants, geopolitical foundations, and prospective challenges

Inicijativa triju mora: geografske odrednice, geopolitička utemeljenja i budući izazovi 
HRVATSKI

GEOGRAFSKI

GLASNIK

80/1, 99-124 (2018.) term directly derived from the term Heartland, marking the opposition to Heartland and thereby creating a dyad. The area that closely resembles Rimland was titled the Inner Crescent by Mackinder (1904: 435, shown on the map titled: The Natural Seats of Power). Eastern Europe is one of the most important parts of Spykman's Rimland, from where Heartland could be put under pressure more easily, due to favourable geography and the relative exposure of the Russian core (from the west) to maritime powers.

\section{The Three Seas Initiative as a revival of historical geopolitical ideas}

The Initiative seems like a revival of geopolitical ideas and initiatives from the first half of the $20^{\text {th }}$ century, mainly from the Inter-War period. If the Initiative would, in the future, include Ukraine and possibly Moldova, or at least accept them fully as adjoined states, it could be considered as a renewed and enlarged Austria-Hungary (expanded to the north and east). The Initiative could also be perceived as an emulation of the geopolitical idea known as Intermarium (Polish: Międzymorze, Croatian: Međumorje), dating from 1919-1920, before the outbreak of the Polish-Soviet Russia War. One of the names of the Initiative, the Three Seas Initiative, clearly shows its connection with the historical Intermarium initiative. The federation would be comprised of the Baltic States (Estonia, Latvia, and Lithuania), Finland, Belarus, Ukraine, Hungary, Romania, as well as the multinational states of the day, the Kingdom of Serbs, Croats and Slovenes (from 1929, the Kingdom of Yugoslavia) and Czechoslovakia. It was proposed by the Polish ruler, Marshall Pilsudski. Intermarium was predominantly devised as idea of an axis of states, based mostly on the ethnic principle and opposed to Soviet Russia. However, it was not backed by most Western Powers, apart from France. Because Belarus and Ukraine were later integrated into Soviet Russia, and Intermarium was viewed as a threat to the newly acquired independence of their countries by some circles in Lithuania and Ukraine (this independence of Ukraine however lasted for only a brief and turbulent period, just until 1921), it was never realised in its original form. Yet another French-backed idea of an alliance of Central and South-Eastern European states, La Petite Entente (the ma Heartland, koji označuje njegovu suprotnost i tako stvara binarnost. Prostor koji vrlo podsjeća na Rimland Mackinder je nazvao Inner Crescent 'Unutarnji prsten' (1904: 435, prikazan na karti nazvanoj The Natural Seats of Power). Istočna Europa bila je jedan od najvažnijih dijelova Spykmanova Rimlanda, od kojega se moglo lakše staviti Heartland pod pritisak, zbog pogodna reljefa i relativne izloženosti jezgre Rusije (sa zapada) pomorskim silama.

\section{Inicijativa triju mora kao oživljenje povijesnih geopolitičkih ideja}

Inicijativa izgleda kao oživljenje geopolitičkih ideja i inicijativa iz prve polovine 20. stoljeća, posebice iz međuratnoga razdoblja. Ako bi Inicijativa u budućnosti uključivala Ukrajinu i možda Moldaviju ili bi one bile potpuno prihvaćene kao pridružene članice, mogla bi se smatrati kao obnovljena i uvećana Austro-Ugarska monarhija (proširena na sjever $\mathrm{i}$ istok). Inicijativa se može smatrati i nasljednikom geopolitičke ideje poznate kao Intermarium (poljski: Międzymorze, hrvatski: Međumorje), nastale 1919. - 1920. godine, prije izbijanja Poljsko-sovjetskoga rata. Jedno od imena Inicijative, Inicijativa triju mora, pokazuje očitu povezanost s povijesnom inicijativom Intermariuma. Federacija se trebala sastojati od Estonije, Latvije, Litve, Finske, Bjelorusije, Ukrajine, Mađarske, Rumunjske i tada postojećih višenacionalnih država, Kraljevine Srba, Hrvata i Slovenaca (od 1929. godine Kraljevina Jugoslavija) i Čehoslovačke. Inicijativu je predložio tadašnji poljski vladar maršal Pilsudski. Intermarium je prvenstveno bio zamišljen kao ideja osovine država, zasnovanih uglavnom na načelu etniciteta i suprotstavljenih Sovjetskoj Rusiji. Međutim, s izuzetkom Francuske, Intermarium nije dobio podršku zapadnih sila. S obzirom na to da su Bjelorusija i Ukrajina kasnije uklopljene u Sovjetsku Rusiju, a Intermarium je bio doživljavan kao prijetnja novostečenoj neovisnosti njihovih država u nekim krugovima u Litvi i Ukrajini (neovisnost Ukrajine potrajala je doduše samo jedno kratko i turbulentno razdoblje, do 1921. godine), ideja nikad nije ostvarena onako kako je izvorno zamišljena. Još jedna ideja saveza država srednje i jugoistočne Europe, poduprta od 
Little Entente), was envisioned as an alliance between Czechoslovakia, Romania, and the Kingdom of Serbs, Croats, and Slovenes. All three states had common interests projected against Hungary. France was mainly interested in keeping the influence of Germany low and therefore wanted an alliance with Germany's other neighbours. What Intermarium and the Little Entente had in common was that they had the support, albeit objectively limited and dubiously successful, of one of the great powers of the period: France. The influence of France, although it was victorious in the First World War, was limited; as it did not share territorial contact with the states that were supposed to comprise the never-realised Intermarium or the Little Entente. The contemporary Initiative has similar goals to Intermarium - containing Russian influence and drawing the states between the EU/NATO and Russia (Ukraine, Belarus, and Moldova) completely out of the Russian sphere of influence, thereby promoting the interests of the U.S., as the great power that now plays a role, similar to that of France in the Inter-War period.

The Initiative is also reminiscent of the more recent Vilnius Group (Estonia, Latvia, Lithuania, Slovenia, Slovakia, Romania, Bulgaria, Croatia, Albania, and Macedonia) plus the three first post-communist NATO member states and firm supporters of the attack on Iraq in 2003 (Poland, Czech Republic, and Hungary). Most of the Vilnius group states (Croatia and Slovenia being the exceptions) joined the "coalition of the willing" in 2003. At the 2002 NATO Prague Summit, seven states of the Vilnius Group were invited to join NATO. At the 2008 NATO Bucharest Summit, Albania and Croatia received their invitations, becoming full members in 2009, while Macedonia (FYROM) was blocked (and still is, at the time of writing) by Greece. In 2017, Montenegro joined NATO as well, becoming the $29^{\text {th }}$ member state.

\section{The Three Seas Initiative as a geopolitical wedge between Germany and Russia}

There are a couple of commonalities that have to be taken into account before analysing the contemporary and possible future geopolitical and geo-economic significance of the Initiative:
Francuske, Mala antanta (La Petite Entente), zamišljena je kao savez Čehoslovačke, Rumunjske i Kraljevine Srba, Hrvata i Slovenaca. Sve tri države imale su zajedničke interese, projicirane protiv $\mathrm{Ma}$ đarske. Francuska je bila prvenstveno zainteresirana za držanje utjecaja Njemačke na niskoj razini i stoga je željela savez s njezinim susjedima. Zajedničko Intermariumu i Maloj antanti je to što su imali potporu, iako objektivno ograničenu i upitno uspješnu, jedne od velikih sila toga razdoblja, Francuske. Iako je bila pobjednica u Prvom svjetskom ratu, utjecaj Francuske međutim bio je ograničen jer nije imala teritorijalni dodir s državama koje su trebale činiti nikad ostvareni Intermarium ili su činile Malu antantu. Suvremena Inicijativa ima slične ciljeve kao Intermarium - zaustavljanje ruskoga utjecaja i izvlačenje država koje se nalaze između EU-a/NATO-a i Rusije (Ukrajina, Bjelorusija i Moldavija) potpuno iz sfere ruskoga utjecaja, promičući tako interese SAD-a, kao velike sile koja sada igra sličnu ulogu koju je Francuska imala u razdoblju nakon Prvoga svjetskog rata.

Inicijativa također evocira sjećanja na noviju Vilniusku skupinu (Estonija, Latvija, Litva, Slovenija, Slovačka Republika, Rumunjska, Bugarska, Hrvatska, Albanija i Makedonija) uz tri prve postkomunističke članice NATO-a, snažne podupirateljice napada na Irak 2003. godine (Poljska, Češka Republika i Mađarska). Većina država članica Vilniuske skupine (Hrvatska i Slovenija bile su iznimke) pridružile su se „koaliciji voljnih” 2003. Na sastanku na vrhu NATO-a 2002. u Pragu sedam država članica Vilniuske skupine pozvano je u članstvo NATO-a. Na sastanku na vrhu NATO-a u Bukureštu 2008. pozivnicu su dobile Albanija i Hrvatska, postavši članicama 2009., dok je poziv Makedoniji blokirala Grčka (još uvijek to čini). Crna Gora se također pridružila NATO-u 2017., kao njegova 29. članica.

\section{Inicijativa triju mora kao geopolitički klin izme- đu Njemačke i Rusije}

Nekoliko je zajedničkih obilježja koja treba uzeti u obzir prije analize suvremenoga i mogućega budućeg geopolitičkog i geoekonomskog značenja Inicijative:
The Three Seas Initiative: geographical determinants, geopolitical foundations, and prospective challenges

Inicijativa triju mora: geografske odrednice, geopolitička utemeljenja i budući izazovi 
HRVATSKI

GEOGRAFSKI

GLASNIK

80/1, 99-124 (2018.)
- Initially, the Initiative was supposed to connect the Baltic and the Adriatic Seas, and it would be mainly a "Catholic club", more conservative than the states of the Western and Northern Europe, especially in the matters of refugee quotas and the acceptance of immigrants in general. Romania and Bulgaria joined the Initiative later, transforming it into the Three Seas Initiative.

- Some states express illiberal tendencies, putting liberal democracy and freedom into question. The afore-mentioned gap between the "Old" and "New" (paraphrasing Rumsfeld's division, which obviously persists) Europe is visible in a variety of issues 5 .

- All the states of the Initiative except Austria are post-communist NATO and EU members, and the Baltic States are post-Soviet states as well.

- Despite the unanimity in their support for sanctions against Russia, support for NATO's role in Europe, and their more or less expressed compliance with U.S. foreign policy since the 1990s, the member states of the Initiative have expressed quite different levels of anti-Russian rhetoric and calls for action. Therefore, two informal groups can be identified among the states of the Initiative. Poland, Estonia, Latvia, Lithuania, Romania, and Croatia (due to the shift in its policy since 2015) comprise the group of "New Cold Warriors", while Austria, Bulgaria, Hungary, Slovakia, and Slovenia can be designated as the "Pragmatics" (Kurečić, 2017), due to their more pragmatic policy and better economic and political relations with Russia, originating mainly from their dependence on Russian gas (Chyong and Tcherneva, 2015), a lesser sense of perceived threat from Russia, and economic motives comprised of the pursuit for future opportunities for their firms on the Russian market, once EU sanctions against Russia are abolished.

Since the early 1990s, NATO and the U.S. have taken a firm foothold in Central and South-Eastern Europe. From the perspective of core NATO mem-

5 "Freedom House's 2013 Nations in Transit report noted that only two (Latvia and the Czech Republic) out of 10 Central European countries have improved their democracy 'scorecard' after (all these studied states, author's remark) being members of NATO and the European Union for over a decade. The other eight countries' ratings dropped in the areas of media freedom, electoral processes, judicial independence, and corruption" (Conley 2015, 30).
- Inicijativa je isprva trebala povezivati Baltičko i Jadransko more te biti prvenstveno „katolički klub", konzervativniji od država zapadne i sjeverne Europe, posebice u pitanjima izbjegličkih kvota i općenito prihvata imigranata. Rumunjska i Bugarska Inicijativi su se priključile kasnije, pretvarajući je u sadašnju Inicijativu triju mora.

- Neke države pokazuju neliberalne tendencije, dovodeći u pitanje liberalnu demokraciju. Spomenuti jaz između „Stare” i „Nove” Europe (parafraza Rumsfeldove podjele, koja očito traje) vidljiv je u mnoštvu pitanja. ${ }^{5}$

- Sve države osim Austrije su postkomunističke članice NATO-a i EU-a, a baltičke države također su i postsovjetske države.

- Usprkos jedinstvenom stavu u potpori sankcijama usmjerenima protiv Rusije, potpori ulozi NATO-a u Europi i njihovoj više ili manje izraženoj podložnosti američkoj vanjskoj politici još od 1990-ih godina, države članice Inicijative izražavaju prilično različitu razinu proturuske retorike i poziva na akciju. Stoga je moguće identificirati dvije neformalne skupine među državama članicama Inicijative. Poljska, Estonija, Latvija, Litva, Rumunjska i Hrvatska (zbog promjene svoje politike od 2015.) čine skupinu "novih ratnika hladnoga rata”, dok se Austrija, Bugarska, Mađarska, Slovačka i Slovenija zbog pragmatičnije politike i boljih gospodarskih i političkih odnosa s Rusijom, ponajviše kao posljedice ovisnosti u ruskom plinu (Chyong and Tcherneva, 2015), manje izraženom osjećaju ugroženosti od Rusije i gospodarskih motiva sadržanih u potrazi za budućim prilikama za vlastite tvrtke na ruskom tržištu jednom kada sankcije EU-a budu ukinute mogu opisati kao „pragmatici” (Kurečić, 2017).

Od ranih 1990-ih godina NATO i SAD zauzeli su snažno uporište u srednjoj i jugoistočnoj Europi. S gledišta stožernih članica NATO-a pristupanje

\footnotetext{
5 „U Nations in Transit izvještaju Freedom Housea za 2013. godinu samo su dvije (Latvija i Češka Republika) od deset država srednje Europe poboljšale svoju demokratsku bilancu iako su (sve ove istraživane države, op. a.) članicama NATO-a i EU postale prije više od desetljeća. Položaj ostalih osam država se pogoršao u području medijskih sloboda, izbornih procesa, neovisnosti pravosuđa te korupcije" (Conley, 2015, 30).
} 
bers, newer NATO members' accession represents a spreading of the zone of security and stability, liberal norms and values, as well as market economy and gaining strategic footholds in the former Soviet Eastern Europe. On the other hand, and despite its fears from NATO expansion and aggression, on its borders and in its surroundings, Russia is facing objectively weaker NATO member states. Therefore, these NATO members are bandwagoning towards the U.S., which openly accepts and "encourages" their alignment.

Hamilton $(2013,304)$ points out that the decisions made at the NATO's 2010 Lisbon (the Strategic Concept was accepted then) and 2012 Chicago Summits successfully balanced Eastern European concerns about security with an overall effort to improve relations with Russia. The relations between the post-communist NATO members and the U.S. have, for the past 25 years, developed mostly by way of security cooperation. After the events in Ukraine, these relations have gained new urgency.

It has to be emphasised that without firm NATO support, these states (even Poland) do not stand a real chance in any kind of direct conflict with Russia: 'The newer members of NATO - countries that directly experienced both Russian and Soviet occupation and hegemonic policies - are apprehensive about this forceful new Russia that does not hesitate to advance neo-colonial claims and practice cyberattacks and energy cut-offs, but their leverage within NATO is limited and can be countered by sticks or carrots in other parts of the world' (Rachwald 2011: 122-123).

If NATO was not present in Central and parts of South-Eastern Europe, the whole region would by now probably be deep in the Russian zone of influence (again). Prior to the Ukrainian crisis, NATO perceived international relations in a more functional sense, similar to the EU. After the events of 2014 in Ukraine, NATO refocused back to its core mission - territorial defence of its members, along with the added tasks of dealing with the contemporary asymmetric security challenges, such as terrorism and hybrid warfare. Nevertheless, the problem for NATO in its reactions towards Russia in the Georgian and Ukrainian crises, respectively, could be seen in the ambivalence of goals and instruments used, primarily comprised in the intent to invite these two states into NATO and the active support for this goal. novijih članica NATO-a predstavlja širenje pojasa sigurnosti i stabilnosti, liberalnih norma i vrijednosti, kao i tržišnoga gospodarstva te zauzimanje strateških uporišta u nekadašnjoj sovjetskoj istočnoj Europi. S druge strane, usprkos vlastitim strahovima od širenja i agresije NATO-a Rusija na svojim granicama i u svojem okruženju ima objektivno slabije članice NATO-a. Stoga se te NATO članice priklanjaju SAD-u, koji konstantno promiče i potiče njihov ulazak u savezništvo.

Hamilton (2013, 304) naglašuje da su odluke NATO-a donesene na sastancima na vrhu u Lisabonu 2010. (tada je donesen Strateški koncept) i u Chicagu 2012. godine uspješno uravnotežile sigurnosne bojazni država članica NATO-a s istoka Europe s općenitim naporima za poboljšanje odnosa s Rusijom. Odnosi između postkomunističkih članica NATO-a i SAD-a su se u prošlih 25 godina razvijali prvenstveno kroz sigurnosnu suradnju. Nakon događaja u Ukrajini ti su odnosi dobili nov zamah.

Treba naglasiti da bez čvrste potpore NATO-a spomenute države (čak ni Poljska) nemaju realne šanse u bilo kakvom odmjeravanju snaga s Rusijom: „Novije članice NATO-a - države koje su izravno iskusile rusku i sovjetsku okupaciju i hegemonske politike - straši nasilna, nova Rusija, koja ne oklijeva promicati svoje neokolonijalne zahtjeve i prakticirati cyber-napade i prekide opskrbe energijom, no njihova poluga utjecaja unutar NATO-a je ograničena i može joj se parirati mrkvom i batinom u drugim dijelovima svijeta" (Rachwald, 2011: 122-123).

Kada NATO ne bi bio prisutan u srednjoj i dijelovima jugoistočne Europe, čitava regija bi dosad vjerojatno već bila duboko u sferi ruskoga utjecaja. Prije ukrajinske krize NATO je međunarodne odnose doživljavao više u funkcionalnom smislu, slično kao EU. Nakon događaja u Ukrajini 2014. NATO ponovno radi na ostvarivanju svoje glavne misije - obrane teritorija svojih članica, uz borbu protiv suvremenih asimetričnih sigurnosnih izazova, kao što su terorizam i hibridno ratovanje. Međutim, NATO-ov problem u odgovorima prema Rusiji u gruzijskoj i ukrajinskoj krizi leži u dvosmislenosti njegovih ciljeva i upotrijebljenih sredstava, prvenstveno namjere da se te dvije države prime u članstvo NATO-a i u tome se potiču.
The Three Seas Initiative: geographical determinants, geopolitical foundations, and prospective challenges

Inicijativa triju mora: geografske odrednice, geopolitička utemeljenja i budući izazovi 
HRVATSKI

GEOGRAFSKI

GLASNIK

80/1, 99-124 (2018.)
Stronger binding of the post-communist EU/ NATO member states plus Austria and maybe in the future Bosnia and Herzegovina, as well as Montenegro and possibly Albania, would create an even more powerful geopolitical axis/wedge of primarily NATO member states that bandwagon (with varying degrees of enthusiasm) towards the U.S., and represent a wedge between the core of the EU (Germany, France, Belgium, Luxembourg, and up to a point, the Netherlands) and Russia. The influence of the post-communist EU/NATO member states is stronger if they cooperate and take a unanimous stance regarding certain foreign policy and security issues, as well as the internal organisation of the EU. The question of the debate about the Five scenarios on the future of the EU, proposed by the President of the European Commission, Jean-Claude Junker, is one of the most important issues on which the states of the Initiative can cooperate and probably come up with an agreed stance. Poland, considering its size, economic power, voting weight in the bodies of the $\mathrm{EU}$, geopolitical position, and military capabilities, is the most important state and the "natural" leader of the Initiative.

Additionally, the pragmatic stance towards Russia, of almost half of the Initiative's states, means that "the Russia issue" certainly is not and will not be its only raison d'etre. The foreign policy goals and areas of cooperation that are available to the states of the Initiative are much wider - protecting national sovereignty from "Bruxelles", a "tough" stance towards the acceptance of refugees and asylum seeker quotas imposed by the EU as a whole, and firm support for the defence cooperation between the EU and NATO, thereby accentuating the role of the U.S. and its interests in European security. Pursuant to these goals, some NATO member states have already sent troops to Poland and Lithuania and participated in military exercises.

However, good relations, political and economic, between some of Initiative's member states and Russia, as well as joint tendencies towards "illiberal democracy" cannot be omitted, especially when it comes to Russian President Putin and Hungarian Prime Minister Orban. Hungary has clear economic interests in cooperation with Russia, as it imports Russian gas and Russia is constructing a second bloc of Soviet-style Hungarian nucle-
Snažnije povezivanje postkomunističkih članica NATO-a/EU-a plus Austrija te u budućnosti možda i Bosne i Hercegovine, Crne Gore i Albanije stvorilo bi još jaču geopolitičku os, prvenstveno država članica NATO-a koje se priklanjaju (iako do vrlo različita stupnja) $\mathrm{SAD}-\mathrm{u}$ te stvaraju klin između jezgre EU-a (Njemačka, Francuska, Belgija, Luksemburg te donekle Nizozemska) i Rusije. Utjecaj postkomunističkih članica NATO-a/EU-a jači je ako surađuju i zauzimaju zajedničko stajalište prema određenim vanjskopolitičkim i sigurnosnim pitanjima, kao i prema unutarnjoj organizaciji EU-a. Pitanje debate o Pet scenarija o budućnosti EU-a, koje je predložio sadašnji predsjednik Europske komisije Juncker, jedno je od najvažnijih pitanja na kojem države Inicijative mogu surađivati i vjerojatno iznaći zajedničko stajalište. Poljska, s obzirom na svoju veličinu, gospodarsku moć, glasačka prava u tijelima EU-a, geopolitički položaj i vojne sposobnosti najvažnija je država i "prirodni“ vođa Inicijative.

Istodobno, pragmatično stajalište prema Rusiji gotovo polovine država članica Inicijative pokazuje da „pitanje Rusije“ sigurno nije i neće biti jedini razlog njezina postojanja. Vanjskopolitički ciljevi i područja suradnje koji su na raspolaganju članicama Inicijative mnogo su širi - zaštita nacionalnoga suvereniteta od Bruxellesa, prilično čvrsto stajalište prema prijemu izbjeglica i kvotama za tražitelje azila koje je donijela EU kao cjelina, čvrsta potpora obrambenoj suradnji EU-a i NATO-a, koja znači naglašavanje uloge SAD-a i njegovih interesa u europskoj sigurnosti. Neke članice NATO-a poslale su svoje postrojbe u Poljsku i Litvu te su sudjelovale u vojnim vježbama.

Međutim, dobri politički i gospodarski odnosi između nekih država Inicijative i Rusije, kao i zajedničke simpatije prema „neliberalnoj demokraciji" ne mogu se zanemariti, pogotovo kad su u pitanju ruski predsjednik Putin i mađarski premijer Orban. Mađarska ima jasne gospodarske interese za suradnju s Rusijom jer uvozi ruski plin, a Rusija gradi drugi blok mađarske nuklearne elektrane u Paksu, izgra- 
ar power plants in Paks. Hungary was, already in 2008, before the events in Georgia and Ukraine, the only NATO member state from "New Europe" that opposed the acceptance of these states to NATO's Membership Action Plan (MAP). The Hungarian stance in 2008 shows how much Hungarian official policy has changed from the period of support for U.S. official policy in the 1990s and early 2000s (Pouliot, 2010: 222).

The U.S., due to the geopolitical and geo-economic interests of its political and military elite, as well as some of its economic elite (large stakeholders in arms industry, oil and gas industry, and coal mining), has a clear interest in supporting NATO and maintaining the anti-Russian stance of NATO members from Central and South-Eastern Europe at a high degree. These kinds of relations evoke memories of the "Jalta" division of Europe, and in that sense, maintain the old European divisions. In order to decrease the influence and annul the interests of the EU core, the member states of the Initiative have chosen two mutually-enforcing strategies:

- Allying and protecting their national interests in the domain of politics and economy - taking joint stances on issues such as energy supply diversification policy, and the opposition to mandatory refugee quotas etc.

- Relying heavily, in security matters, on NATO, to which they, in reality (except Poland) contribute negligibly (only Estonia contributes with more than two percent of its GDP, however it is a small economy and a country with only 1.3 million inhabitants), except as strategic outposts and territories on which NATO bases can be stationed. The majority of the Initiative's NATO member states are "freeriders", and their defence spending is well below the recommended two percent of GDP. Because their economies have a significantly lower GDP per capita than most of the other NATO member states (except Greece and Turkey, which heavily compensate with contributions well above two percent of GDP) and these are mostly small and mid-size states, their nominal financial contributions to NATO are well below the average. This reliance on NATO ties them closely to the U.S., which dominates the security sphere, and weakens the political in- đene u sovjetskom razdoblju. Mađarska je već 2008., prije događaja u Gruziji i Ukrajini, bila jedina država „Nove Europe“ koja se protivila primanju tih država u Akcijski plan za članstvo NATO-a (MAP). Stajalište Mađarske 2008. godine pokazalo je koliko se službena mađarska politika promijenila od razdoblja potpore američkoj službenoj politici u 1990-im i ranim 2000-im godinama (Pouliot, 2010: 222).

Sjedinjene Države, zbog geopolitičkih i geoekonomskih interesa svoje političke i vojne elite te dijelova svoje gospodarske elite (veliki dionici u industriji oružja, industriji nafte i plina, ugljenokopima) imaju jasan interes podupirati NATO i održavati proturuski stav članica NATO-a iz srednje i jugoistočne Europe na visokoj razini. Ovakav tip odnosa podsjeća na podjelu Europe iz Jalte te u tom smislu održava stare europske podjele. Kako bi smanjile utjecaj država jezgre EU-a, države članice Inicijative izabrale su dvije strategije koje se međusobno osnažuju:

- Stvaranje saveza i zaštita nacionalnih interesa u području politike i gospodarstva - zauzimanje zajedničkih stajališta u pitanjima politike diversifikacije dobave energije te protivljenje obveznim kvotama za prihvat izbjeglica.

- Snažno oslanjanje u sigurnosnim pitanjima na NATO, kojem u stvarnosti (osim Poljske) doprinose gotovo zanemarivo (jedino Estonija izdvaja više od $2 \% \mathrm{BDP}$-a za obranu, međutim, radi se o maloj ekonomiji i državi sa samo 1,3 milijuna stanovnika), osim kao strateški isturena uporišta i teritoriji na kojima NATO može postaviti svoje baze. Većina država članica NATO-a koje su i članice Inicijative su tzv. free riders „slobodni strijelci” jer su njihova izdvajanja za obranu daleko ispod preporučenih $2 \% \mathrm{BDP}-\mathrm{a}$. Budući da gospodarstva tih država imaju značajno niži postotak BDP-a od većine ostalih država članica NATO-a (osim Grčke i Turske, koje međutim ovo snažno kompenziraju izdvajanjima puno većima od $2 \%$ BDP-a) i uglavnom se radi o malim državama i državama srednje veličine, njihov nominalni financijski doprinos NATO-u daleko je ispod prosjeka. Oslanjanje na NATO približava ih SAD-u, koji dominira u sigurnosnoj sferi
The Three Seas Initiative: geographical determinants, geopolitical foundations, and prospective challenges

Inicijativa triju mora: geografske odrednice, geopolitička utemeljenja i budući izazovi 
HRVATSKI

GEOGRAFSKI

GLASNIK

80/1, 99-124 (2018.) fluence of the states of the EU core, particularly Germany.

If the Brexit process would be completed and a "hard Brexit" would be accomplished, the U.S. would lose its most reliable ally in the EU, whose bargaining powers and influence have already markedly decreased. Therefore, Poland and other post-communist EU member states have gained importance for the U.S. and can serve as a backbone of the strategy striving for a weaker, divided Europe of strong nation states.

There are clear signs that the EU Core (and Germany particularly) and the Initiative's member states are increasingly moving away from each other regarding the issues of security, reliance on energy supply, and immigration. Most of the Initiative's member states (especially the forerunners, Poland, Estonia, Latvia, Lithuania, Romania, and Croatia) rely on the U.S. as their protector. On the other hand, the states of the EU Core want to develop the defence policy of the EU further, which would not exclude NATO, but it would lower its relevance and the degree of unanimity on the "Russia issue". The states of the EU Core do not share hard anti-Russian rhetoric and are not included in the strategic projects that Russia classifies as primary threats to its security (the anti-ballistic missile shield, located in Poland, the Czech Republic, and Romania, is the best example thereof). Germany and France, as well as Belgium and Luxembourg, were against the de facto involvement of NATO into the U.S.-UK attack on Iraq in 2003, and against the invitation of Ukraine and Georgia into the NATO's Membership Action Plan to that was supposed to be announced in December, 2008. This invitation, which represented the first real step towards NATO membership, would certainly have antagonised Russia, and was to be sent out only four months after the 2008 FiveDay War in Georgia, in which Russia clearly showed (as it showed later in Ukraine) its perception of what represented a "red line" for NATO's influence in the Post-Soviet Space, which it treats as its "Near Neighbourhood". Even since 2014 and the outbreak of the crisis in Ukraine and the Russian annexation of the Crimea peninsula, the countries of the EU Core have always opted for a diplomatic approach towards Russia, albeit openly condemning the annexation and supporting EU sanctions against Russia. te tako oslabljuje politički utjecaj država jezgre EU-a, posebice Njemačke.

Ako proces Brexita bude dovršen i ostvari se „tvrdi Brexit”, SAD bi izgubio svoga najvjernijeg saveznika u EU-u, čija su se moć u pregovorima i utjecaj već dosad ubrzano smanjili. Stoga su Poljska i ostale postkomunističke članice EU-a dobile na važnosti i mogu služiti kao okosnica strategije kojoj je cilj slabija, podijeljena Europa jakih nacionalnih država.

Postoje jasni znakovi da se države jezgre EU-a (Njemačka posebice) i države članice Inicijative ubrzano razilaze u pitanjima sigurnosti, oslanjanja na dobavu energije i imigracije. Većina država članica Inicijative (pogotovo njezini protagonisti Poljska, baltičke države, Rumunjska i Hrvatska) oslanja se na $\mathrm{SAD}$ vidjevši ga kao svoga zaštitnika. S druge strane, države jezgre EU-a žele dalje razvijati obrambenu politiku EU-a, koja ne bi isključivala NATO, ali bi umanjila njegovu važnost i stupanj jedinstva oko „pitanja Rusije”. Države jezgre EU-a nemaju snažnu proturusku retoriku i nisu uključene u strateške projekte koje Rusija smatra glavnim prijetnjama vlastitoj sigurnosti (protubalistički raketni štit, smješten u Poljskoj, Češkoj Republici i Rumunjskoj, najbolji je primjer). Njemačka i Francuska, kao i Belgija i Luksemburg, bili su protiv de facto uključivanja NATO-a u američko-britanski napad na Irak 2003. godine te protiv pozivanja u Akcijski plan za članstvo NATO-a Ukrajine i Gruzije, koje je trebalo biti objavljeno u prosincu 2008. godine. Ta pozivnica, koja je prvi pravi korak prema članstvu u NATO-u, sigurno bi antagonizirala Rusiju, a bilo je planirano da se pošalje samo četiri mjeseca nakon Petodnevnoga rata 2008. u Gruziji, u kojem je Rusija prethodno jasno pokazala (kao što je kasnije pokazala u Ukrajini) što je u njezinoj percepciji ,crvena linija” NATO-ova utjecaja u postsovjetskom prostoru, koji Rusija smatra svojim „bližim susjedstvom”. Čak i nakon 2014. godine i izbijanja krize Ukrajini i ruske aneksije poluotoka Krima države jezgre EU-a uvijek su zagovarale diplomatski pristup prema Rusiji iako osuđuju aneksiju i podupiru sankcije EU-a prema Rusiji. 


\section{The most important demographic, geopolitical and geo-economic challenges to the Initiative}

The combined population of the post-communist EU/NATO member states (the Initiative minus Austria) is approximately 20 million larger than the population of Germany, while their economies combined (GDP: 1,303.3 billion USD, 2016) are almost three times smaller than the German economy (GDP: 3,477.8 billion USD, 2016), and slightly larger than the economies of Spain (GDP: 1,232 billion USD, 2016) or Russia (GDP: 1,283 billion USD, 2016) (World Bank, 2017c). Poland is the biggest post-communist EU/NATO state, which connects the Initiative's central and northern parts, and seems that it is determined to be the informal leader of the group, as it has almost two-times larger population than the second-largest Initiative member state, Romania. Poland has about 37 percent of the population of the post-communist EU/ NATO member states in question, and comprises about 36 percent of their combined economy.

When the demographic situation in the post-communist states of Europe has been studied, Atoyan et al. (2016: 8) point out: 'During the past 25 years, nearly 20 million people ( $5 \frac{1}{2} / 2$ percent of the Central and South-Eastern Europe population) are estimated to have left the region. By the end of 2012, South-Eastern Europe had experienced the largest outflows, amounting to about 16 percent of the early-1990s population. Between 1990 and 2012, outward migration from South-Eastern Europe shaved off more than 8 percentage points from cumulative population growth'. Most of the Initiative's member states are faced with serious demographic challenges that are common primarily to its Baltic and South-Eastern European members, with Hungary as the Visegrad Group member state facing similar challenges that can be summed up in two main aspects - very low birth rate, and the increased rate of emigration. This came about after accession to the EU, presenting the afore-mentioned countries with the largest emigration wave in their recent history (Tab. 1).

Besides the trends that are a product of historical events (breakups of the Soviet Union and Yugoslavia) and had nothing to do with accession to the EU, the gradual or instant opening of the EU
Najvažniji demografski, geopolitički i geoekonomski izazovi Inicijativi

Ukupan broj stanovnika postkomunističkih članica EU-a i NATO-a (Inicijativa osim Austrije) otprilike je za 20 milijuna veći od stanovništva Njemačke, dok su njihova gospodarstva zajedno (BDP: 1 303,3 milijarde američkih dolara 2016. godine) gotovo triput manja nego gospodarstvo Njemačke (BDP: 3 477,8 milijarda američkih dolara 2016. godine), a nešto malo veća od gospodarstva Španjolske (BDP: 1232 milijarde američkih dolara 2016. godine) ili Rusije (BDP: 1283 milijarda američkih dolara 2016. godine) (World Bank, 2017c). Poljska je najveća postkomunistička država članica EU-a i NATO-a, koja spaja središnji i sjeverni dio Inicijative te se čini da je odlučna biti neformalni vođa skupine s obzirom na to da ima gotovo dvostruko veći broj stanovnika od Rumunjske, druge najveće članice Inicijative. Poljska ima oko 37 \% stanovništva svih postkomunističkih država članica EU-a i NATO-a te oko $36 \%$ njihova ukupnoga gospodarstva.

Kad je u pitanju demografska slika postkomunističkih europskih država, Atoyan i dr. (2016: 8 ) ističu da se „procjenjuje da je u posljednjih 25 godina gotovo 20 milijuna ljudi $(5,5 \%$ stanovništva srednje i jugoistočne Europe) napustilo regiju. Do kraja 2012. godine jugoistočna Europa pretrpjela je najveći odljev stanovništva, koji iznosi oko 16 \% stanovništva iz ranih 1990-ih godina. Od 1990. do 2012. godine emigracija iz jugoistočne Europe smanjila je kumulativni rast stanovništva za više od $8 \%$ ”. Najveći dio država članica Inicijative suočen je s ozbiljnim demografskim izazovima, prisutnima prvenstveno u njezinim baltičkim i jugoistočnoeuropskim članicama te Mađarskoj kao članici Višegradske skupine suočenoj sa sličnim izazovima koji se mogu predstaviti kroz dva glavna aspekta vrlo nizak natalitet i povećana stopa iseljavanja. Upravo nakon pristupa EU-u spomenute države suočene su s najvećim iseljeničkim valom u svojoj novijoj povijesti (tab. 1).

Osim trendova koji su proizvod povijesnih procesa (raspad Sovjetskoga Saveza i Jugoslavije) i nisu imali veze s pristupom EU-u, postupno ili trenutačno otvaranje pristupa tržišta rada EU-a
The Three Seas Initiative: geographical determinants, geopolitical foundations, and prospective challenges

Inicijativa triju mora: geografske odrednice, geopolitička utemeljenja i budući izazovi 
HRVATSKI

GEOGRAFSKI

GLASNIK

80/1, 99-124 (2018.)
Tab. 1 Population, demographic loss, and net migration of the Three Seas Initiative member states

Tab. 1. Stanovništvo, demografski gubitak i migracijski saldo država Inicijative Tri mora

\begin{tabular}{|c|c|c|c|c|c|c|c|c|}
\hline 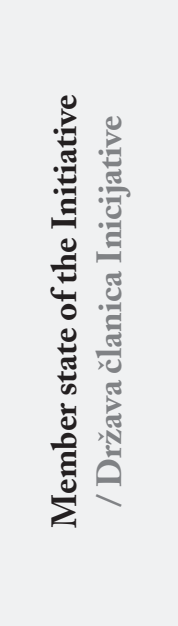 & 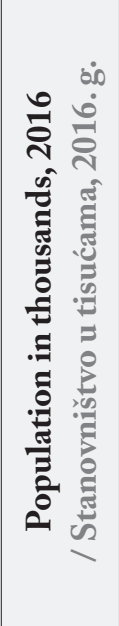 & 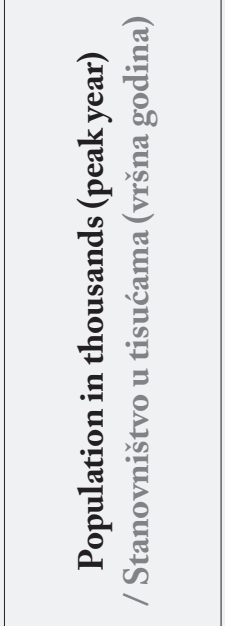 & 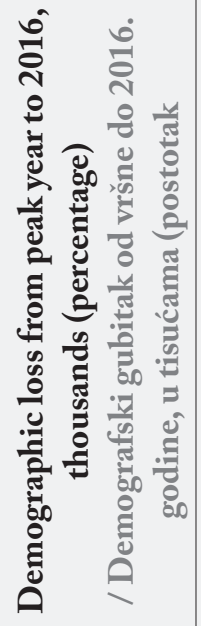 & 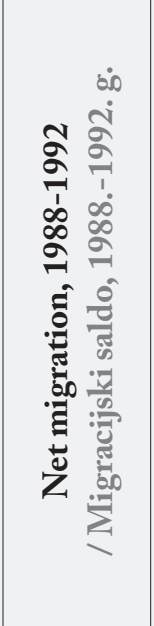 & 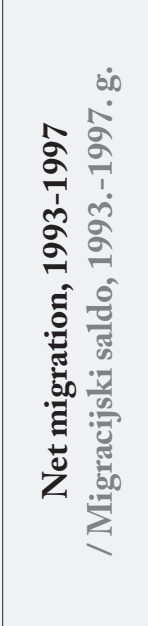 & 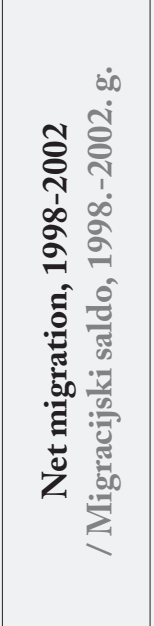 & 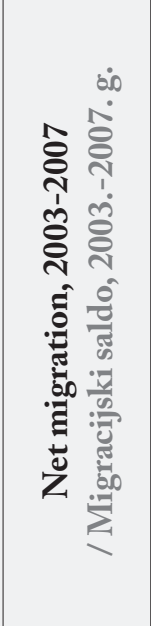 & 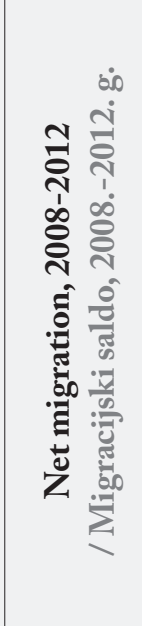 \\
\hline $\begin{array}{l}\text { Austria } \\
\text { / Austrija }\end{array}$ & 8747 & / & / & 227841 & 65082 & 178117 & 153763 & 267172 \\
\hline $\begin{array}{l}\text { Bulgaria / } \\
\text { Bugarska }\end{array}$ & 7128 & 8981 (1988) & 1853 (20.6) & -356464 & -133824 & -85500 & -83472 & -24772 \\
\hline $\begin{array}{l}\text { Croatia } \\
\text { / Hrvatska }\end{array}$ & 4171 & 4780 (1990) & 609 (12.7) & -143579 & -188129 & -2580 & -10499 & -32772 \\
\hline $\begin{array}{l}\text { Czech } \\
\text { Republic } \\
\text { / Češka } \\
\text { Republika }\end{array}$ & 10562 & / & / & 29999 & 46002 & 47402 & 250889 & 59997 \\
\hline $\begin{array}{l}\text { Estonia } \\
\text { / Estonija }\end{array}$ & 1316 & $1569(1990)$ & $253(16.1)$ & -111876 & -1197 & -18406 & -15151 & -10516 \\
\hline $\begin{array}{l}\text { Hungary } \\
\text { / Mađarska }\end{array}$ & 9818 & $10712(1981)$ & $894(8.3)$ & 99980 & 78562 & 61589 & 25150 & 29999 \\
\hline $\begin{array}{l}\text { Latvia } \\
\text { / Latvija }\end{array}$ & 1960 & 2667 (1989) & $707(26.5)$ & -116474 & -46601 & -72490 & -86594 & -83325 \\
\hline $\begin{array}{l}\text { Lithuania } \\
\text { / Litva }\end{array}$ & 2872 & 3704 (1991) & $832(22.5)$ & -100301 & -93925 & -99104 & -150930 & -146217 \\
\hline $\begin{array}{l}\text { Poland } \\
\text { / Poljska }\end{array}$ & 37948 & 38660 (1999) & $712(1.8)$ & -159999 & -85199 & -183471 & -178456 & -73997 \\
\hline $\begin{array}{l}\text { Romania } \\
\text { / Rumun- } \\
\text { jska }\end{array}$ & 19705 & $23202(1990)$ & $3497(15.1)$ & -520001 & -610000 & -468204 & -774651 & -299997 \\
\hline $\begin{array}{l}\text { Slovakia } \\
\text { / Slovačka } \\
\text { Republika }\end{array}$ & 5429 & / & / & -15108 & -2964 & 1199 & -8855 & 11346 \\
\hline $\begin{array}{l}\text { Slovenia / } \\
\text { Slovenija }\end{array}$ & 2065 & / & / & -17461 & 1487 & 14998 & 39348 & 16571 \\
\hline
\end{tabular}

Source / lzvor: World Bank (2017f; 2017g)

116 
labour market (depending on the decisions of particular EU member states after the enlargements of 2004, 2007, and 2013, respectively) has been the most significant factor that negatively influenced the demographic characteristics of most of the Initiative's member states ${ }^{6}$. The second factor with primarily economic implications (besides the EU accession) that has negatively influenced the demographics of the Initiative's states was the Great Recession that hit the Baltic States the worst (especially in 2009) and Croatia the longest (six years of continuous, double-dip recession).

Even among the 11 post-communist member states of the Initiative, and without performing quantitative demographic research, it is possible to see a difference in demographic trends in the last 25 years, with Poland showing much lower net demographic loss than South-Eastern and Baltic members of the Initiative, while the Czech Republic, Slovakia, and Slovenia do not show any net demographic loss. Smart and timely implementation of population policies, more favourable economic trends, and the absence of ethnic and/or religious minorities that would emigrate on a massive scale due to specific historical conditions have made this positive difference (Fig. 2).

Considering only Germany, the biggest economy and labour market of the EU, as the most frequent destination of labour migrants from the post-communist EU member states, the data for the year 2016 were as follows: Out of total 634,000 EU citizens that immigrated to Germany in 2016, 77 percent originated from post-communist members, with Romania (171,380 migrants, $0.87 \%$ of the total population in 2016), Poland $(123,134$, or $0.32 \%)$, Bulgaria $(66,790,0.94 \%)$, Croatia $(51,163$, $1.23 \%)$ and Hungary $(42,302,0.43 \%)$ as the main originating countries (Bundesamt für Migration und Flüchtlinge, 2017). The trends are especially negative, from the position of the out migration states, and especially for Bulgaria, Romania, and Croatia, the three least developed and most recent EU member states.

6 "Emigration from Central, Eastern, and South-Eastern Europe has been unusually large, persistent, and dominated by educated and young people. The South-Eastern European economies typically saw appreciably larger labour outflows than the Baltic and Central European countries" (Atoyan et al., 2016, 5). (ovisno o odlukama pojedinih država članica nakon proširenja iz 2004., 2007. i 2013. godine) bio je glavni čimbenik koji je negativno utjecao na demografske značajke većine država članica Inicijative. ${ }^{6}$ Drugi čimbenik s primarno gospodarskim implikacijama (osim proširenja EU-a) koji je negativno utjecao na demografiju država Inicijative bila je recesija, koja je najjače pogodila baltičke države u najizazovnijoj, 2009. godini, dok je Hrvatska iskusila najdulju recesiju (šest godina kontinuirane recesije s dvostrukim minimumom).

Čak i među 11 postkomunističkih država članica Inicijative, već i bez provođenja kvantitativnoga demografskog istraživanja, moguće je opaziti razliku $\mathrm{u}$ demografskim trendovima u posljednjih 25 godina, pri čemu Poljska pokazuje mnogo manji neto demografski gubitak od baltičkih i jugoistočnoeuropskih članica Inicijative, dok Češka Republika, Slovačka Republika i Slovenija uopće ne pokazuju neto demografski gubitak. Pametne i na vrijeme primijenjene populacijske mjere, povoljniji gospodarski trendovi te odsutnost etničkih $\mathrm{i} / \mathrm{ili}$ vjerskih manjina koje bi zbog specifičnih povijesnih okolnosti masovno emigrirale zaslužni su za ovu pozitivnu razliku (sl. 2).

Uzimajući u obzir samo Njemačku, najveće gospodarstvo i tržište rada u EU-u, kao najčešce odredište ekonomskih migranata iz postkomunističkih država članica EU-a, podaci za 2016. godinu pokazuju da je od ukupno 634 tisuće državljana EU-a koji su se doselili u Njemačku 2016. godine $77 \%$ podrijetlom iz postkomunističkih članica, pri čemu su glavne države podrijetla bile Rumunjska (171 380 migranata, 0,87 \% ukupnoga stanovništva 2016. godine), Poljska (123 134, 0,32 \%), Bugarska (66 790, 0,94 \%), Hrvatska (51 163, 1,23 \%) i Mađarska (42 302, 0,43 \%) (Bundesamt für Migration und Flüchtlinge, 2017). Trendovi su posebice negativni, iz pozicije država iz kojih se iseljava, za Bugarsku, Rumunjsku i Hrvatsku, tri najmanje razvijene i najnovije članice EU-a.

6 „Emigracija iz srednje, istočne i jugoistočne Europe neuobičajeno je visoka, ustrajna i u njoj dominiraju obrazovani i mladi ljudi. Ekonomije jugoistočne Europe doživjele su bitno veće odljeve radne snage nego baltičke države i države srednje Europe.” (Atoyan i dr., 2016, 5).
The Three Seas Initiative: geographical determinants, geopolitical foundations, and prospective challenges

Inicijativa triju mora: geografske odrednice, geopolitička utemeljenja i budući izazovi 
HRVATSKI

GEOGRAFSKI

GLASNIK

80/1, 99-124 (2018.)

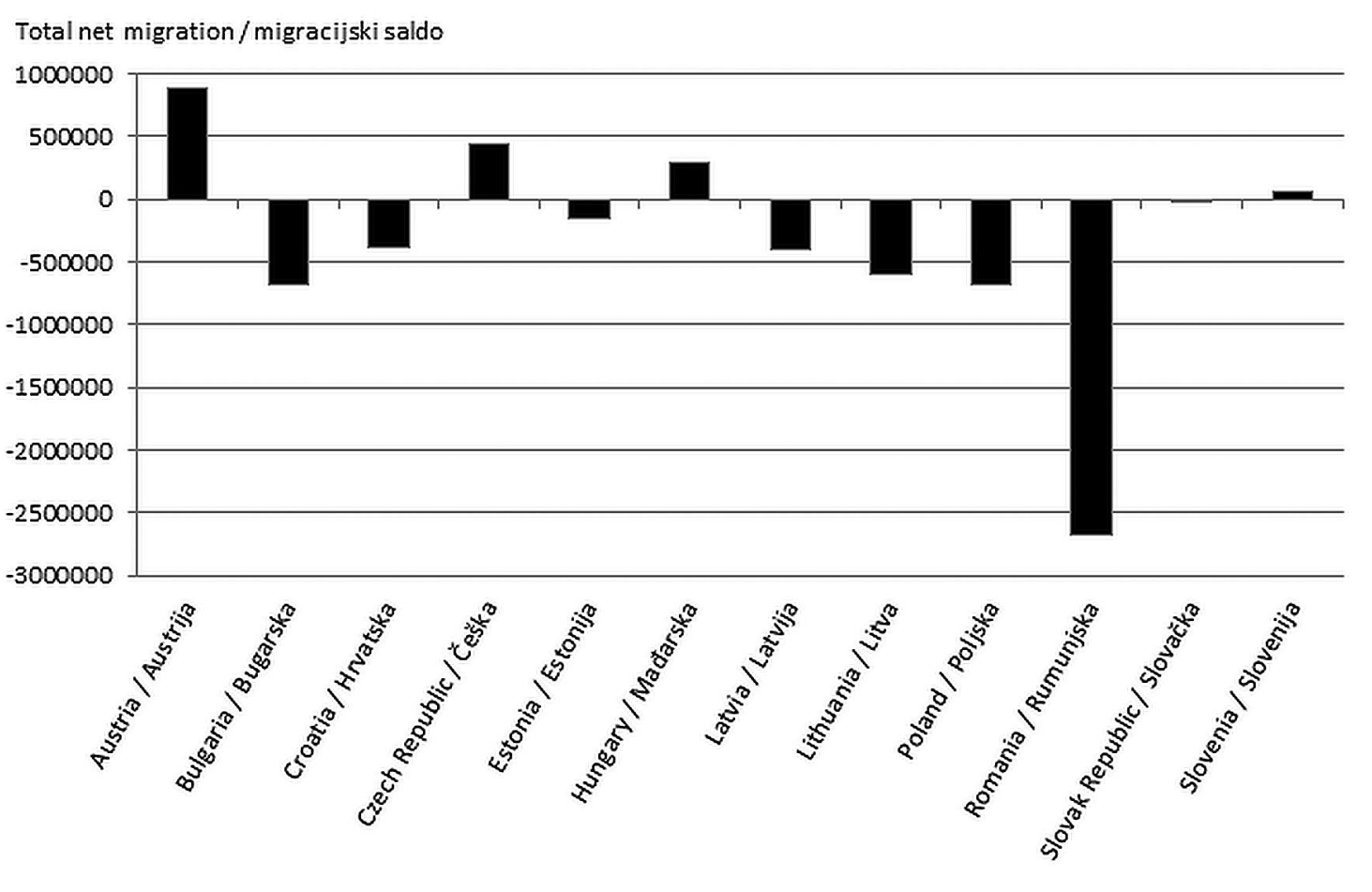

Fig. 2 Net migration of the Three Seas Initiative member states, 1988-2012 SI. 2. Migraciijki saldo država Inicijative Tri mora, 1988-2012. godine Source / Izvor: World Bank (2017f)

In Table 2, total GDP, GNI per capita, armed personnel size, defence spending as percentage of GDP, arms imports, and length of the borders of the Initiative's states with non-NATO and non-Initiative countries are shown. The data for the number of armed personnel are deliberately shown for the years 2013 (the last year before the full-scale crisis and war in Ukraine, as decisive moments that made relations with Russia very difficult and tense, broke out) and 2015, the last year for which the data were available, in order to see are there any significant differences. Similar applies for the defence spending as a percentage of the GDP, shown for the years 2013 and 2016 (the last year for which the data were available) (Tab. 2).

Most of the Initiative's member states did not enlarge their armed forces personnel significantly, despite the outbreak of the Ukrainian crisis, Russian annexation of the Crimea peninsula, and assertive Russian military policy in the Baltic region and on the Black Sea. The only exceptions are Estonia and
U Tablici 2 prikazani su ukupan BDP, bruto društveni dohodak po stanovniku, brojnost oružanih snaga, vojni izdaci kao postotak BDP-a, iznos uvoza oružja i duljina granice članica Inicijative prema državama koje nisu članice ni Inicijative ni NATO-a. Podaci za brojnost oružanih snaga namjerno su prikazani za 2013. (posljednju godinu prije izbijanja krize i rata u Ukrajini, kao odlučujućih momenata koji su otežali i pogoršali odnose s Rusijom) i 2015. godinu, posljednju godinu za koju su podaci bili dostupni, kako bi se pokušalo uočiti značajnije razlike. Slično vrijedi za vojne izdatke kao postotak BDP-a, koji su prikazani za 2013. i 2016. godinu (posljednja godina za koju su podaci bili dostupni) (tab. 2).

Većina država članica Inicijative nije znatnije povećala brojnost svojih vojnih snaga usprkos izbijanju krize u Ukrajini, ruske aneksije poluotoka Krima i nametljive ruske vojne politike na Baltiku i Crnom moru. Iznimke su Estonija i Litva, koje su povećale brojnost svojih vojnih snaga za 
Tab. 2 Total GDP, GNI per capita, armed forces size, military expenses, arms imports, and the length of the external borders of the Three Seas Initiative member states

Tab. 2. Ukupan BDP, bruto društveni dohodak po stanovniku, brojnost oružanih snaga, vojni izdaci, iznos uvoza oružja i duljina vanjskih granica dřžava Inicijative Tri mora

\begin{tabular}{|c|c|c|c|c|c|c|c|}
\hline 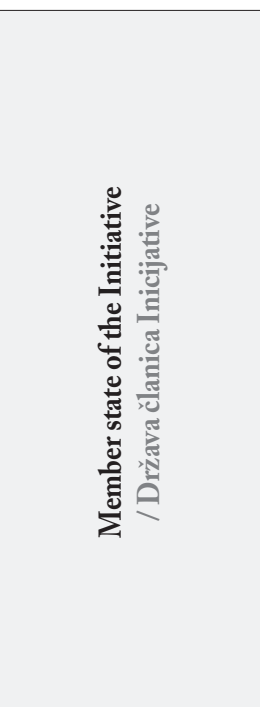 & 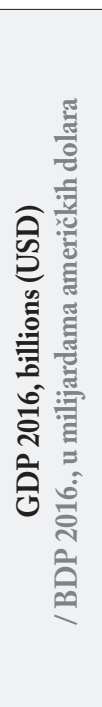 & 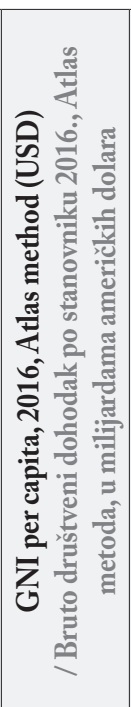 & 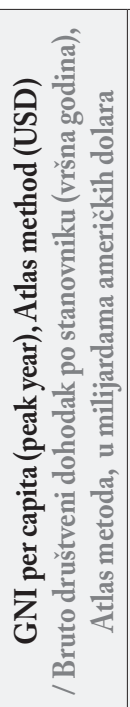 & 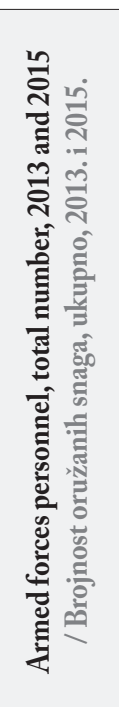 & 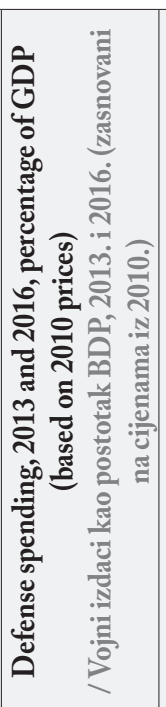 & 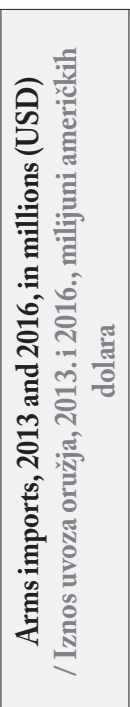 & 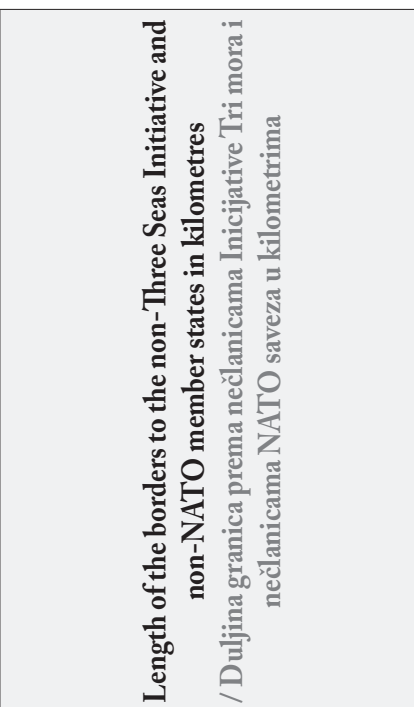 \\
\hline $\begin{array}{l}\text { Austria } \\
\text { / Austrija }\end{array}$ & 386.4 & 45230 & $\begin{array}{l}50500 \\
(2013)\end{array}$ & $\begin{array}{l}22500 \\
21350\end{array}$ & $\begin{array}{l}0.8 \\
0.7^{*}\end{array}$ & $\begin{array}{c}7 \\
13 \\
\end{array}$ & $\begin{array}{l}\text { Liechtenstein / Lihtenštajn: } 34 \\
\text { Switzerland / Švicarska: } 158\end{array}$ \\
\hline $\begin{array}{l}\text { Bulgaria } \\
\text { / Bugarska }\end{array}$ & 52.4 & 7470 & $\begin{array}{l}7720 \\
(2014)\end{array}$ & $\begin{array}{l}47300 \\
47300\end{array}$ & $\begin{array}{l}1.46 \\
1.35\end{array}$ & $\begin{array}{l}\mathrm{n} / \mathrm{a} \\
\mathrm{n} / \mathrm{a}\end{array}$ & $\begin{array}{l}\text { Macedonia / Makedonija: } 162 \\
\text { Serbia / Srbija: } 344\end{array}$ \\
\hline $\begin{array}{l}\text { Croatia } \\
\text { / Hrvatska }\end{array}$ & 50.4 & 12110 & $\begin{array}{l}14050 \\
(2011)\end{array}$ & $\begin{array}{l}19550 \\
18550\end{array}$ & $\begin{array}{l}1.47 \\
1.23\end{array}$ & $\begin{array}{l}\mathrm{n} / \mathrm{a} \\
32\end{array}$ & $\begin{array}{l}\text { Bosnia-Herzegovina / Bosna i } \\
\text { Hercegovina: } 956 \\
\text { Serbia / Srbija: } 314\end{array}$ \\
\hline $\begin{array}{l}\text { Czech Republic } \\
\text { / Češka Republika }\end{array}$ & 192.9 & 17570 & $\begin{array}{l}19420 \\
(2011)\end{array}$ & $\begin{array}{l}24100 \\
25050\end{array}$ & $\begin{array}{l}1.03 \\
1.04\end{array}$ & $\begin{array}{c}15 \\
0\end{array}$ & / \\
\hline $\begin{array}{l}\text { Estonia } \\
\text { / Estonija }\end{array}$ & 23.1 & 17750 & $\begin{array}{l}18790 \\
(2014)\end{array}$ & $\begin{array}{l}5750 \\
6400\end{array}$ & $\begin{array}{l}1.90 \\
2.16\end{array}$ & $\begin{array}{l}18 \\
27\end{array}$ & Russia / Rusija: 324 \\
\hline $\begin{array}{l}\text { Hungary } \\
\text { / Mađarska }\end{array}$ & 124.3 & 12570 & $\begin{array}{l}13460 \\
(2014)\end{array}$ & $\begin{array}{l}38500 \\
38500 \\
\end{array}$ & $\begin{array}{l}0.95 \\
1.01 \\
\end{array}$ & $\begin{array}{c}2 \\
17 \\
\end{array}$ & $\begin{array}{l}\text { Serbia / Srbija: } 164 \\
\text { Ukraine / Ukrajina: } 128 \\
\end{array}$ \\
\hline $\begin{array}{l}\text { Latvia } \\
\text { / Latvija }\end{array}$ & 27.7 & 14630 & $\begin{array}{l}15330 \\
(2014)\end{array}$ & $\begin{array}{l}5310 \\
5310\end{array}$ & $\begin{array}{l}0.93 \\
1.45 \\
\end{array}$ & $\begin{array}{c}5 \\
40 \\
\end{array}$ & $\begin{array}{l}\text { Belarus / Bjelorusija: } 161 \\
\text { Russia / Rusija: } 332\end{array}$ \\
\hline $\begin{array}{l}\text { Lithuania } \\
\text { / Litva }\end{array}$ & 42.7 & 14770 & $\begin{array}{l}16030 \\
(2014)\end{array}$ & $\begin{array}{l}21950 \\
28330\end{array}$ & $\begin{array}{l}0.76 \\
1.49\end{array}$ & $\begin{array}{l}73 \\
20\end{array}$ & $\begin{array}{l}\text { Belarus / Bjelorusija: } 640 \\
\text { Russia (Kaliningradska oblast) / } \\
\text { Rusija (Kalinjingradska oblast): } 261\end{array}$ \\
\hline $\begin{array}{l}\text { Poland } \\
\text { / Poljska }\end{array}$ & 469.5 & 12680 & $\begin{array}{l}13630 \\
(2014)\end{array}$ & $\begin{array}{l}172700 \\
172700\end{array}$ & $\begin{array}{l}1.72 \\
2.00\end{array}$ & $\begin{array}{l}152 \\
170\end{array}$ & $\begin{array}{l}\text { Belarus / Bjelorusija: } 418 \\
\text { Russia (Kaliningradska oblast) / } \\
\text { Rusija (Kalinjingradska oblast): } 210 \\
\text { Ukraine / Ukrajina: } 535\end{array}$ \\
\hline $\begin{array}{l}\text { Romania } \\
\text { / Rumunjska }\end{array}$ & 186.7 & 9470 & $\begin{array}{l}9600 \\
(2014)\end{array}$ & $\begin{array}{l}151300 \\
150400\end{array}$ & $\begin{array}{l}1.28 \\
1.48\end{array}$ & $\begin{array}{c}20 \\
183\end{array}$ & $\begin{array}{l}\text { Moldova / Moldavija: } 683 \\
\text { Serbia / Srbija: } 531 \\
\text { Ukraine / Ukrajina: } 601\end{array}$ \\
\hline $\begin{array}{l}\text { Slovakia } \\
\text { / Slovačka Republika }\end{array}$ & 89.6 & 16810 & $\begin{array}{l}18140 \\
(2013)\end{array}$ & $\begin{array}{l}15850 \\
15850\end{array}$ & $\begin{array}{l}0.99 \\
1.16\end{array}$ & $\begin{array}{c}6 \\
\mathrm{n} / \mathrm{a}\end{array}$ & Ukraine / Ukrajina: 97 \\
\hline Slovenia / Slovenija & 44.0 & 21660 & $\begin{array}{l}24710 \\
(2008)\end{array}$ & $\begin{array}{l}13550 \\
13200 \\
\end{array}$ & $\begin{array}{l}1.06 \\
0.94\end{array}$ & $\begin{array}{l}\mathrm{n} / \mathrm{a} \\
\mathrm{n} / \mathrm{a}\end{array}$ & / \\
\hline
\end{tabular}

* The data for Austria were taken from the World Bank; hence it is not a NATO member state. The last year for which the data were available was 2015. / Podaci za Austriju preuzeti su sa stranica Svjetske banke s obzirom na to da nije članica NATO-a. Posljednji dostupni podaci bili su za 2015. godinu. Source / Izvor: NATO (2016); World Bank (2017a; 2017b; 2017c; 2017d; 2017e)
P. Kurečić

The Three Seas

Initiative:

geographical

determinants,

geopolitical

foundations,

and prospective

challenges

Inicijativa triju mora: geografske odrednice, geopolitička utemeljenja i budući izazovi 
HRVATSKI

GEOGRAFSKI

GLASNIK

80/1, 99-124 (2018.)
Lithuania, which have increased their armed forces personnel by about 10 and 30 percent, respectively. In 2015, the total armed forces personnel of the 11 NATO/EU member states (Austria excluded) that are also members of the Initiative, was about 522,000 members (Poland and Romania contributed to that number with about 323,000). In 2015, Russia's armed forces boasted roughly $1,490,000$ members, so the ratio between the armed forces personnel of the 11 NATO members of the Initiative and Russia was about 1:3 (without considering Russia's dominance in terms of armoured vehicles and aircraft, as well as the fact that Russia is one of two nuclear superpowers). If we add Belarussian armed forces $(158,000$ members in 2015), as an allied state, to Russian forces, the ratio is even more in favour of Russia. Therefore, NATO represents an indispensable security guarantor for member states in Central and South-Eastern Europe, and particularly to those located in the possible Baltic and Black Sea theatres of war, with smaller Central European NATO members that share border with Ukraine (Slovakia and Hungary) being exposed as well, but to a lesser point - due to their geographical location and pragmatic policy towards Russia (for example, these countries do not host THAAD anti-ballistic missile systems, like those found in Poland, the Czech Republic, and Romania).

Defence expenses as percentage of GDP (presented for the years 2013 and 2016) showed that only two NATO/Initiative member states (Poland and Estonia) complied with NATO's recommendation of two percent of GDP. Due to the small size of Estonia, only Poland can be considered as a member state of the Initiative with a respectable military force that also currently complies with NATO's recommendation, especially because Poland has rather modern weapons and systems (modern fighter airplanes, Patriot missile defence systems, navy vessels, etc.). Most of the $11 \mathrm{NATO} /$ Initiative member states did not significantly increase their defence spending (Bulgaria, Croatia, and Slovenia even decreased it) after the Ukrainian crisis; the exceptions are the Baltic States and Poland, which feel most exposed to Russia's presence, "with Kaliningradska oblast as a forward strategic base of Russia, and the Suwalki Gap, an ' $80 \mathrm{~km}$ patch of relatively flat, difficult to defend countryside' (Brook, 2017), as the weakest otprilike 10 i 30 posto. Ukupna brojnost vojnih snaga članica NATO-a i EU-a (bez Austrije) koje su ujedno i članice Inicijative bila je oko 522 tisuće pripadnika (na Poljsku i Rumunjsku otpadalo je oko 323 tisuće). Rusija je 2015. godine imala oružane snage koje su brojile milijun i 490 tisuća pripadnika, stoga je odnos između oružanih snaga 11 država članica NATO-a i Inicijative i Rusije bio otprilike $1: 3$ (bez uzimanja u obzir dominaciju Rusije u oklopnim vozilima i zrakoplovima te činjenicu da je Rusija jedna od dviju nuklearnih supersila). Ako se ruskim vojnim snagama pridodaju i snage Bjelorusije (158 tisuća pripadnika 2015. godine), kao savezničke države Rusiji, odnos je još više u korist Rusije. Stoga je NATO nezamjenjiv jamac sigurnosti za svoje članice iz srednje i jugoistočne Europe, posebice one smještene na mogućem baltičkom i crnomorskom ratištu, dok su manje srednjoeuropske članice NATO-a koje imaju granicu s Ukrajinom (Slovačka Republika i Mađarska) također izložene, ali u manjoj mjeri - zbog svoga geografskog položaja i pragmatične politike prema Rusiji (te države primjerice na svom teritoriju nisu smjestile protubalističke raketne sustave THAAD, za razliku od Poljske, Češke Republike i Rumunjske).

Vojni izdaci kao postotak BDP-a (prikazani za 2013. i 2016. godinu) otkrivaju da su samo dvije članice NATO-a i Inicijative (Poljska i Estonija) poštivale preporuku NATO-a o izdvajanju $2 \%$ BDP-a za obranu. S obzirom na činjenicu da je Estonija mala država, jedino se Poljska može smatrati državom članicom Inicijative s respektabilnim vojnim snagama, a koja ujedno i poštuje preporuku NATO-a, pogotovo jer Poljska posjeduje prilično moderna oružja i sustave (moderni lovački zrakoplovi, proturaketni obrambeni sustavi Patriot, ratni brodovi itd.). Većina od 11 država članica Inicijative i NATO-a nije bitnije povećala svoja izdvajanja za obranu nakon krize u Ukrajini (Bugarska, Hrvatska i Slovenija čak su ih smanjile). Iznimke su samo baltičke države i Poljska, koje se osjećaju najviše izložene ruskoj prisutnosti - „, Kalinjingradskom oblašću kao isturenom strateškom bazom Rusije i koridorom Suwalki, 80 km širokim procijepom relativno ravnoga, teško branjiva ru- 
point that connects Poland and Lithuania, separating Kaliningradska oblast from Belarus. If the Suwalki Gap would be closed by Russian and Belarussian forces, the three Baltic members of NATO would be territorially cut off from Poland and the rest of the Alliance (Grigas, 2016). Additionally, the activities of the Russian Baltic Fleet and Russian air force are showing a renewed presence and assertiveness of Russia on the sea and in the air.

The data on the length of borders to non-NA$\mathrm{TO} /$ non-Initiative states mostly correlate with the increase in defence spending of Initiative's member states; hence the fact that the states that have the longest non-NATO border with Russia and/or Belarus (the Baltic States and Poland), as well as Ukraine (Poland and Romania, which also has a long border with Moldova, a country completely surrounded by Ukraine and Romania, without complete control of its territory) have increased their defence spending the most and expressed the hardest anti-Russian rhetoric and stance.

In energy supply issues and challenges, there seems to be a clear geopolitical and geo-economic initiative towards gradual exclusion of Russia and re-orientation towards the U.S.. The Initiative has declared two large infrastructural projects as its main goals. First is a North-South Highway, called Via Carpathia, a corridor between two important harbours: Klaipeda in Lithuania and Thessaloniki in Greece. The second project is the planned gas pipeline that would connect two future liquefied natural gas (LNG) terminals, one in Poland, and the other on the Croatian island of Krk. Regarding the second main infrastructural project, the gas pipeline between the Adriatic and the Baltic Sea, President Trump's visit to the July, 2017 Summit of the Initiative, held in Warsaw, had geo-economic aspects that were clearly visible in giving significance to diversification of energy suppliers and supply routes to its states, besides having a clear geopolitical meaning, by the expression of unambiguous support to the Initiative and its member states. Trump was in Warsaw to promote U.S. natural gas and coal exports; as the U.S. has become a net exporter of natural gas, thanks to fracking, mostly done in Texas and Pennsylvania (Gotev, 2017). Besides the Initiative member states, Ukraine, due ralnoga prostora“ (Brook, 2017), kao najslabijom točkom koja povezuje Poljsku i Litvu te odvaja Kalinjingradsku oblast od Bjelorusije. Ako bi ruske i bjeloruske snage zatvorile koridor Suwalki, tri baltičke članice NATO-a bile bi teritorijalno odvojene od Poljske i ostatka NATO-a (Grigas, 2016). Osim toga, aktivnosti ruske baltičke flote i ruskoga zrakoplovstva pokazuju ponovnu prisutnost i odrješitost Rusije na moru i u zraku.

Podaci o duljini granica prema nečlanicama Inicijative i nečlanicama NATO-a uglavnom se podudaraju s povećanjem vojnih izdataka država članica Inicijative, stoga vrijedi teza da su države koje imaju najdulje nenatovske granice prema Rusiji i/ili Bjelorusiji (baltičke države i Poljska), kao i prema Ukrajini (Poljska i Rumunjska, koja ima i dugu granicu s Moldavijom, državom potpuno okruženom Ukrajinom i Rumunjskom, bez potpune kontrole teritorija, na čijem se jednom dijelu nalazi Transdnjestarska oblast, koju podržava Rusija) najviše povećale svoje vojne izdatke i imaju najtvrđu retoriku i stav prema Rusiji.

U pitanjima i izazovima opskrbe energijom čini se da postoji jasna geopolitička i geoekonomska inicijativa za postupno isključivanje Rusije i promjena orijentacije prema SAD-u. Inicijativa je objavila dva velika infrastrukturna projekta kao svoje glavne ciljeve. Prvi je autocesta u smjeru sjever-jug, nazvana Via Carpathia, kao koridor između dviju važnih luka: Klaipede u Litvi i Soluna u Grčkoj. Drugi projekt je planirani plinovod, koji bi povezivao dva buduća skladišta ukapljenoga prirodnog plina (UPP), jednoga u Poljskoj i drugoga na otoku Krku. Kad je u pitanju drugi spomenuti projekt, plinovod između Jadranskoga i Baltičkoga mora, posjet američkoga predsjednika Trumpa drugom sastanku na vrhu Inicijative, održanom u srpnju 2017. g. u Varšavi, osim geopolitičkoga značenja, davanjem nedvosmislene potpore Inicijativi i njezinim članicama, imao je i geoekonomske aspekte, koji su bili jasno vidljivi u davanju važnosti diversifikaciji dobavljača i dobavnih ruta energije državama Inicijative. Trump je u Varšavi promovirao izvoz prirodnoga plina i ugljena iz SAD-a jer je SAD zbog frakiranja, koje se obavlja ponajviše u saveznim državama Texasu i Pennsylvaniji postao izvoznik prirodnoga plina (Gotev, 2017). Osim država članica Inicijative,
The Three Seas Initiative: geographical determinants, geopolitical foundations, and prospective challenges

Inicijativa triju mora: geografske odrednice, geopolitička utemeljenja i budući izazovi 
HRVATSKI

GEOGRAFSKI

GLASNIK

80/1,99-124 (2018.) to its heavy industry and energy dependence, needs imported coal, and the U.S. has a surplus of coal as well, which can be imported into Ukraine, mainly via Odessa harbour.

Due to afore-mentioned U.S. geo-economic and geopolitical interests in Central and Eastern Europe, terminating the beginning of the construction of the Nord Stream 2 Pipeline remains a primary objective the U.S. with its main ally Poland supporting the efforts, parallel with the construction of the LNG Terminal on the Croatian island of Krk and the building of gas pipeline interconnectors among the countries of the region. One step further in the attempt to prolong Russian and German dependence on northern transit countries, Belarus and Poland, is the law that was passed by the U.S. Congress in July 2017 (Radio Poland, 2017). While it makes it more difficult for the President to end the sanctions against Russia, it also targets the Russo-German Nord Stream 2 gas pipeline to Europe that would significantly lower or, de facto, end the dependence of Germany and Russia on transit countries. The Nord Stream 2 gas pipeline would significantly lower the geo-economic significance of Poland, because its territory could not be used to partially block the delivery of gas from Russia to Germany. Germany and Austria have castigated new U.S. sanctions on Russia, describing them as an illegal threat to the EU energy security. Berlin and Vienna both stated that the amendment heralded a 'new and very negative quality in European-American relations'. Gas pipeline Nord Stream 2 would also reduce the transit importance and incomes from transit to Ukraine, the sitting government of which is an ally of the U.S. (Foy et al., 2017). In Germany, the bill was perceived as a direct strike at Germany's and the EU's strategic interests, which put its energy supply in jeopardy (Petersdorff, 2017).

\section{Conclusion}

The Initiative has evolved into a geopolitical and geo-economic grouping of primarily post-communist NATO/EU member states. Despite their diversities and some differences in stances towards Russia, the member states of the Initiative are showing certain common interests, such as heavy reliance on NATO as a protector (de facto the U.S. "security umbrella"), determination to lower the dependence on Russian gas,
Ukrajina, zbog svoje teške industrije i ovisnosti o uvozu energije, treba uvozni ugljen, kojega SAD ima i viška te koji se u Ukrajinu može uvoziti prvenstveno kroz luku Odesa.

Zbog spomenutih geoekonomskih i geopolitičkih interesa $S A D-a$ u srednjoj $\mathrm{i}$ istočnoj Europi blokiranje početka izgradnje plinovoda Sjeverni tok 2 ostaje primarni cilj SAD-a, čije napore podupire njegov glavni saveznik Poljska, uz istodobnu izgradnju terminala za ukapljeni prirodni plin na Krku te gradnju spojnica među plinovodima između država regije. Korak dalje u pokušaju da se produlji ovisnost Rusije i Njemačke o tranzitnim državama na sjeveru, Bjelorusiji i Poljskoj, zakon je donesen u Kongresu SAD-a u srpnju 2017. g. (Radio Poland, 2017). Taj zakon predsjedniku SAD-a otežava završetak sankcija prema Rusiji, a također cilja na rusko-njemački projekt plinovoda Sjeverni tok 2, koji bi bitno umanjio tj. de facto prekinuo ovisnost Njemačke i Rusije o tranzitnim državama. Plinovod Sjeverni tok 2 prilično bi umanjio geoekonomsko značenje Poljske jer se njezin teritorij ne bi mogao koristiti za djelomičnu blokadu dopreme plina iz Rusije u Njemačku. Njemačka i Austrija osudile su nove američke sankcije Rusiji, opisujući ih kao nezakonitu prijetnju energetskoj sigurnosti EU-a. Berlin i Beč smatraju da „amandman najavljuje novu, vrlo lošu kvalitetu europsko-američkih odnosa". Plinovod Sjeverni tok 2 također bi smanjio tranzitnu važnost i prihode od tranzita Ukrajini, čija je sadašnja vlada saveznik SAD-a (Foy i drugi, 2017). U Njemačkoj se spomenuti zakon doživljava kao izravan udarac strateškim interesima Njemačke i EU-a, koji ugrožava dobavu energije (Petersdorff, 2017).

\section{Zaključak}

Inicijativa triju mora prerasla je u geopolitičku i geoekonomsku grupaciju primarno postkomunističkih država, članica NATO-a i EU-a. Usprkos različitostima i razlikama u stavovima prema Rusiji države članice Inicijative imaju određene zajedničke interese, kao što su snažno oslanjanje na NATO kao zaštitnika (de facto američki „sigurnosni kišobran"), odlučnost u smanjenju ovisnosti o ruskom 
develop new transit corridors and gas pipelines, and act jointly as a barrier towards a renewed German-French vision of Europe, which comprises a tighter integration of the fiscal and political aspects of the EU. The vision of the EU after Brexit, pursued by the states of the EU Core, as well as the European Commission, means more integration, which is not positively viewed in some of the Initiative's member states, particularly Poland and Hungary, with the Czech Republic and Slovakia, respectively, having doubts as well. The Visegrad Group therefore has emerged as a primary opponent of federalised Europe, with Poland as its logical forerunner. The influence and the objective importance in the EU, of the Baltic States, as well as Croatia, means these are not as significant as larger states, so they definitely cannot act as "game changers" in the afore-mentioned processes. Therefore, these states have connected with the Visegrad Group in the effort to increase their bargaining power, concurrently bandwagoning towards the U.S.. Therefore, the Initiative was created, as a group that primarily emulates the goals and purpose of the Vilnius Group, increasing the influence of its member states (now member states of the EU) and therefore maintaining the EU as a whole weaker, which serves U.S. geopolitical and geo-economic interests. plinu, razvoj novih tranzitnih koridora i plinovoda te zajedničko djelovanje kao brana obnovljenoj njemačko-francuskoj viziji Europe, koja uključuje jaču integraciju fiskalnih i političkih aspekata EUa. Vizija EU-a nakon Brexita, koju promiču države jezgre EU-a i Europska komisija, znači viši stupanj integracije, na što se ne gleda pozitivno u nekim državama članicama Inicijative, posebice u Poljskoj i Mađarskoj, dok Češka Republika i Slovačka Republika također izražavaju dvojbe. Višegradska skupina nameće se stoga kao glavni protivnik federalizirane Europe, s Poljskom kao logičnim predvodnikom. Utjecaj i objektivna važnost baltičkih država i Hrvatske u EU-u, koje nisu važne kao što su to veće države, znači da te države nikako ne mogu biti one koje će donijeti promjenu u spomenutim procesima. Stoga se te države i jesu više povezale s Višegradskom skupinom kako bi povećale svoju važnost u budućim pregovorima, istovremeno se priklanjajući SAD-u. Stvorena je tako Inicijativa, kao grupacija koja prvenstveno nasljeđuje ciljeve i svrhu Vilniuske skupine povećanjem utjecaja svojih država članica (sada država članica EU-a) i tako održava EU kao cjelinu slabijom, što služi američkim geopolitičkim i geoekonomskim interesima.

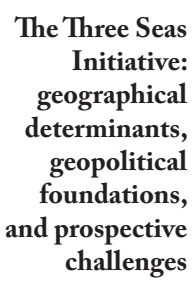

The Three Seas Initiative: geographical determinants, geopolitical foundations, and prospective challenges

Inicijativa triju mora: geografske odrednice, geopolitička utemeljenja i budući izazovi
Armstrong, P. H., Martin, G. (eds.), 2006: Geographers, Biobibliographical Studies 25, Bloomsbury Publishing, London.

Atoyan, R., Christiansen, L., Dizioli, A., Ebeke, C., Ilahi, N., Ilyina, A., Mehrez, G., Qu, H., Raei, F., Rhee, A., Zakharova, D., 2016: Emigration and Its Economic Impact on Eastern Europe, http://www. imf.org/external/pubs/ft/sdn/2016/ sdn1607.pdf (10. 07. 2017.).

Brook, B., 2017: The Suwalki Gap the potential European flashpoint Vladimir Putin is keeping a close eye on, News.com.au, April 24, http:// www.news.com.au/world/europe/ the-suwalki-gap-the-potential-european-flashpoint-vladimir-putin-iskeeping-a-close-eye-on/news-story/ eb51cce0c50f06949a16f9370779338e (27. 12. 2017.).

Chyong, C.-K., Tcherneva, V., 2015: Europe's vulnerability on Russian gas, March 17, http://www.ecfr.eu/article/ commentary_europes_vulnerability_ on_russian_gas (18.07.2017.).

Cohen, S. B., 2003: Geopolitics of the World System, Rowman \& Littlefield, Lanham, MD.

Cohen, S. B., 2008: Geopolitics - The Geography of International Relations, Rowman \& Littlefield, Lanham, MD.

Conley, H. A., 2015: Russia's Influence on Europe, in: Global Forecast 2015 (eds. Cohen, C., Gabel, J.), Center for Strategic and International Studies, Washington, D.C., 28-31.

Dodds, K., Sidaway, J. D, 2004: Halford Mackinder and the 'geographical pivot of history': a centennial retrospective, The Geographical Journal 170 (4), 292-297, DOI: 10.1111/j.00167398.2004.00131.x.

Fairgrieve, J., 1924: Geography and World Power, $5^{\text {th }}$ edition, University of London Press, London.

Foy, H., Sevastopulo, D., Wagstyl, S.,
2017: Berlin hits back at US move to tighten sanctions on Russia, Financial Times, June 15, https://www.ft.com/ content/27e28a44-51b0-11e7-a1f2db19572361bb (29.07. 2017.).

Gotev, G., 2017: Trump to promote US LNG exports at Warsaw summit, Euractiv, 3 July, https://www.euractiv.com/ section/europe-s-east/news/trump-topromote-us-lng-exports-at-warsawsummit/ (25.07.2017.).

Grigas, A., 2016: NATO's Vulnerable Link in Europe: Poland's Suwalki Gap, Atlantic Council, February 9, http://www. atlanticcouncil.org/blogs/natosource/ nato-s-vulnerable-link-in-europe-poland-s-suwalki-gap (27. 12. 2017.).

Hamilton, D., 2013: The changing nature of the transatlantic link: U.S. approaches and implications for Central and Eastern Europe, Communist and Post-Communist Studies 46, 303-313, DOI 10.1016/j.postcomstud.2013.06.001.
Literatura

Literature 
HRVATSKI GEOGRAFSKI GLASNIK 80/1, 99-124 (2018.)

Sources Izvori

Author Autor
Hartshorne, R., 1941: The politico-geographic pattern of the world, The Annals of the American Academy of Political and Social Science 218, 45-57.

Hartshorne, R., 1944: The United States and the 'shatter zone' of Europe, in: Compass of the World (eds. H. Weigert and V. Steffanson), Macmillan, New York, 203-214

Hensel, P. R., Diehl, P. F., 1994: Testing empirical propositions about shatterbelts, 1945-1976, Political Geography 13, 33-52.

Kennedy, P., 2004: The pivot of history, Guardian, June 19, https://www.theguardian.com/world/2004/jun/19/usa. comment (20. 07. 2017.)

Kurečić, P., 2017: The "New Cold Warriors" and the "Pragmatics": The Differences in Foreign Policy Attitudes towards Russia and the Eastern Partnership States among the NATO Member States from Central and South-Eastern Europe, Croatian International Relations Review 23 (80), 61-96, DOI 10.1515/cirr-20170021.

Mackinder, H. J., 1904: The Geographical Pivot of History, The Geographical Journal 23 (4), 421-437.

Morillas, P. (ed.), 2017: Illiberal Democracies in the EU: the Visegrad Group and the Risk of Disintegration, Barcelona Center for International Affairs Publication, Barcelona.

Parker, G., 2014: Western Geopolitical Thought in the 20th Century, Routledge, London.

Petersdorff, W. von, 2017: Wie Amerikas Sanktionen gegen Russland Deutschland treffen, Frankfurter Allegemeine Zeitung, 24 July, http:// www.faz.net/aktuell/wirtschaft/ wirtschaftspolitik/umstrittener-gesetzentwurf-wie-amerikas-sanktionen-gegen-russland-deutschland-treffen-15120165.html (27.07.2017.).

Pouliot, V., 2010: International Security in Practice: The Politics of NATO-Russia Diplomacy, Cambridge University Press, Cambridge.

Rachwald, A. R., 2011: A 'reset' of NATORussia relations: real or imaginary? $E u-$ ropean Security 20 (1), 117-126, DOI: 10.1080/09662839.2011.557366.

Spykman, N. J., 1938: Geography and Foreign Policy I, American Political Science Review 1, 28-50.

Unstead, J. F., 1923: The belt of political change in Europe, The Scottish Geographical Magazine 34, 183-192.

Whittlesey, D., 1942: German Strategy of World Conquest, Farrar and Rinehart, New York.

Bundesamt für Migration und Flüchtlinge, 2017: Freizügigkeitsmonitoring: Migration von EU-Bürgern nach Deutschland, http://www. bamf.de/SharedDocs/Anlagen/DE/Publikationen/Broschueren/freizuegigkeitsmonitoring-jahresbericht-2016.pdf?_blob=publicationFile (15.09.2017)

NATO, 2016: Defence Expenditures of NATO Countries (2009-2016), COMMUNIQUE PR/CP(2016)116, http://www.nato.int/nato_ static_fl2014/assets/pdf/pdf_2016_07/20160704_160704-pr2016-116.pdf (25.07. 2017.).

Radio Poland, 2017: US law offers chance to block Russia-Germany pipeline: Polish deputy FM, http://www.thenews.p1/1/10/Artykul/333211,US-law-offers-chance-to-block-RussiaGermany-pipeline-Polish-deputy-FM (02. 11. 2017).

World Bank, 2017a: Armed forces personnel, total, https://data.worldbank.org/indicator/MS.MIL.TOTL.P1 (27. 12. 2017.).

World Bank, 2017b: Arms imports, https://data.worldbank.org/indicator/MS.MIL.MPRT.KD (27. 12. 2017.).

World Bank, 2017c: GDP, total (current US\$, Atlas method), https://data.worldbank.org/indicator/NY.GDP.MKTP.CD (28. 07. 2017.).

World Bank, 2017d: GNI per capita (current US\$, Atlas method), https://data.worldbank.org/indicator/NY.GNP.PCAP.KD (28. 07. 2017.).

World Bank, 2017e: Military expenditure (\% of GDP), https://data.worldbank.org/indicator/MS.MIL.XPND.GD.ZS (27. 12. 2017.).

World Bank, 2017f: Net migration, https://data.worldbank.org/indicator/SM.POP.NETM (06. 01. 2018.).

World Bank, 2017g: Population, total, https://data.worldbank.org/indicator/SP.POP.TOTL (02. 1. 2018.).

Petar Kurečić petar.kurecic@unin.hr

PhD, Associate Professor, Senior Research Fellow, University North, Trg dr. Žarka Dolinara 1, 48000 Koprivnica, Croatia 